\title{
Analysis of Monetary Policy and Financial Stability: A New Paradigm
}

\author{
Charles A.E. Goodhart \\ Carolina Osorio \\ Dimitrios P. Tsomocos
}

\author{
CESIFO WORKING PAPER NO. 2885 \\ CATEgORY 7: MONETARy POLICY AND INTERNATIONAL FinanCE \\ DECEMBER 2009
}

Presented at CESifo Economic Studies Conference, November 2009

\footnotetext{
An electronic version of the paper may be downloaded

- from the SSRN website: Www.SSRN.com

- from the RePEc website: $\quad$ www.RePEc.org

- from the CESifo website: www.CESifo-group.org/wp
} 


\title{
Analysis of Monetary Policy and Financial Stability: A New Paradigm
}

\begin{abstract}
This paper introduces agent heterogeneity, liquidity, and endogenous default to a DSGE framework. Our model allows for a comprehensive assessment of regulatory and monetary policy, as well as welfare analysis in the different sectors of the economy. Due to liquidity and endogenous default, the transmission mechanism of shocks is well defined, and their short to medium run effects on financial stability are properly captured.
\end{abstract}

JEL Code: D50, E43, E44, E50, G01, G20.

Keywords: general equilibrium, financial fragility, monetary policy, regulation.

Charles A.E. Goodhart

Financial Markets Group

Room R414

London School of Economics and Political Science

Houghton Street

UK - London WC2A 2AE

caegoodhart@aol.com

\author{
Carolina Osorio \\ Said Business School \\ Park End Street \\ UK - Oxford OX1 1HP \\ carolina.osorio@sbs.ox.ac.uk
}

Dimitrios P. Tsomocos

Said Business School

Park End Street

UK - Oxford OX1 1HP

dimitrios.tsomocos@sbs.ox.ac.uk

\section{PRELIMINARY AND INCOMPLETE}

COMMENTS WELCOME

October 2009

We acknowledge the helpful comments from participants at the CESifo Economic Studies Conference (2009) 'What's wrong with Macroeconomics', in particular to Gerhard Illing, participants of the Macroeconomics Workshop at the University of Oxford, Martin Ellison and Paul Beaudry. However, all remaining errors are ours. 


\section{Introduction}

The benchmark DSGE model is a micro-founded representative agent model with real and/or nominal rigidities that incorporates elements of the Real Business Cycle approach and the New Keynesian paradigm, and where monetary policy is conducted by an independent Central Bank which follows an interest rate rule-based approach to stabilize inflation (as suggested by Woodford's 'theory' of monetary policy). DSGEs gained popularity as tools for policy discussion and analysis among academics and central banks because of their usefulness in identifying sources of economic fluctuations, and for forecasting, and predicting the effects of policy interventions. However, the appeal of DSGEs withered during the current financial crisis because they failed to provide a suitable framework for the analysis of financial (in)stability, and it became evident that they lacked essential elements for this purpose.

On the one hand, representative agent models rule out trade between agents, and hence the possibility of default, as so also do transversality conditions; however, a set-up that allows for the existence and modelling of default is required, otherwise there would be no crises. Secondly, while most DSGEs abstract from financial frictions, a model of active heterogeneous banks with different portfolios is needed to allow for the existence of an interbank market and contagious financial crises, as well as to capture the propagation and transmission mechanism of shocks through the financial system. Therefore, money, banks, and interest rates must play an essential role; nevertheless, in Woodford's framework, money and credit arise as inessential additions to the non-monetary version of the model; the means for credit settlement are unspecified, and the nominal interest rate is undefined.

We develop a framework for financial stability analysis by introducing liquidity, endogenous default, and agent heterogeneity into an otherwise canonical Dynamic Stochastic General Equilibrium (DSGE) model. Thus, our model contains financial frictions essential to financial stability analysis, as proposed by the Monetary General Equilibrium literature (Goodhart et.al, 2003, 2006, 2007, 2009 and Tsomocos, 2003), as well as the dynamic and stochastic structure characteristic of DSGEs, which allow for the examination of shock dynamics and the use of actual data for parameter calibration.

The paper proceeds as follows. Section 2 presents the model, in section 3 the equilibrium of the model as well as its properties are described. Section 4 analyses the simulation results, and finally, section 5 concludes.

\section{Model}

The economy is inhabited by two (heterogeneous) households $(\theta, \gamma)$ and two (heterogeneous) commercial banks $(\psi, \delta)$. Household $\theta$ is endowed with labour, purchases consumer goods from $\gamma$, and owns both commercial banks. Household $\gamma$ is a "yeoman farmer", who buys labour from household $\theta$, and produces and sells consumer goods to $\theta$. Both households obtain utility from the consumption of such consumer goods.

Furthermore, household $\theta$ deposits his savings with bank $\psi$, who uses these resources to extend credit in the interbank market. Bank $\delta$ borrows in the interbank credit market both from bank $\psi$ and the Central Bank; and the yeoman farmer takes out corporate credit extensions from bank $\delta$. Finally let $T=\{0,1,2, . . t-1, t, t+1, \ldots\}$ denote de time horizon of the economy.

A diagram of the economy's nominal flows are presented below. 
Figure 1: Nominal Flows of the Economy

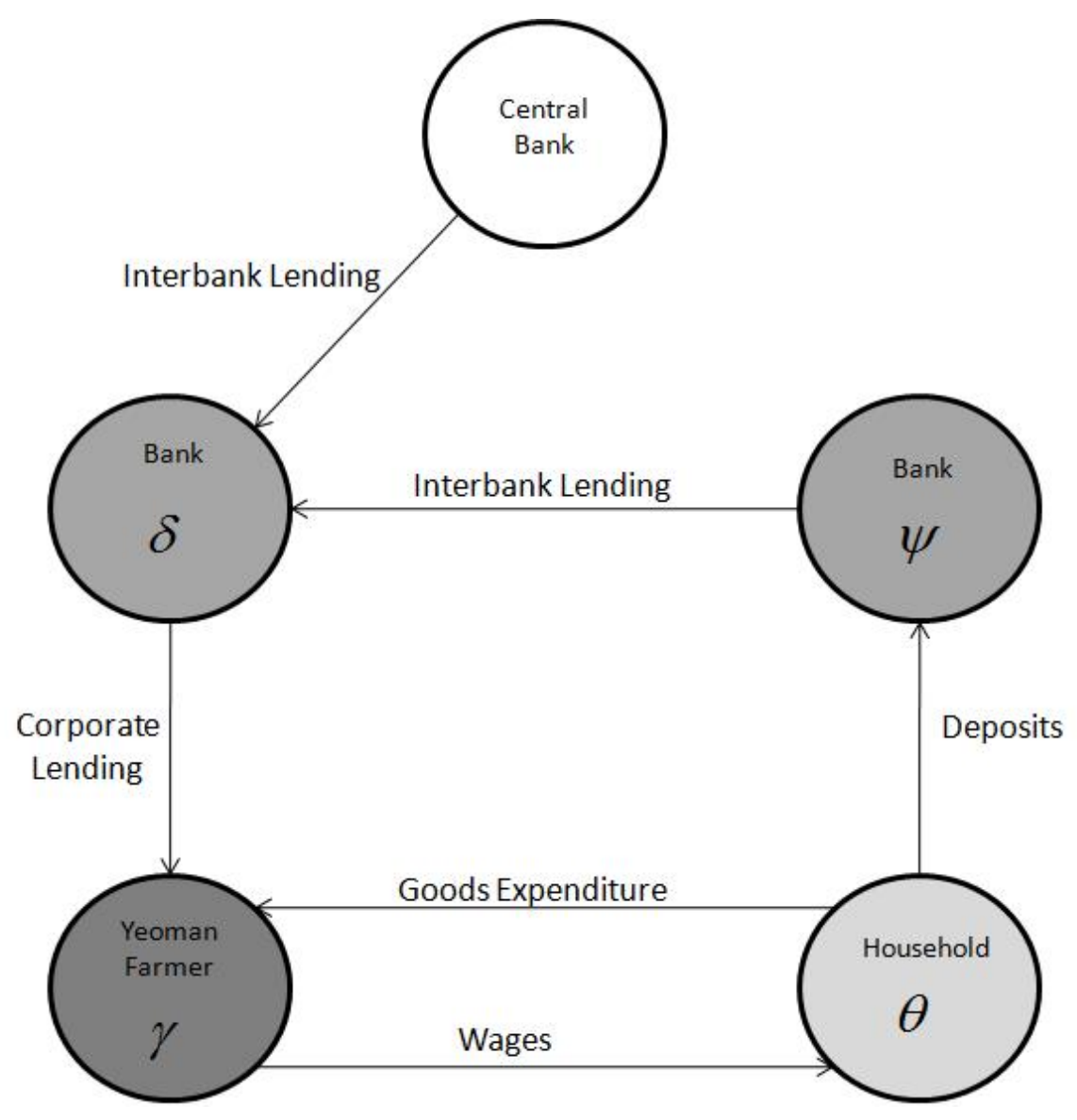




\subsection{Financial Frictions}

As suggested by Tsomocos (2003) and Goodhart et. al (2006), in order to provide an appropriate framework for financial stability analysis, we introduce two essential financial frictions: default and money.

Following Shubik and Wilson (1977) and Dubey et al. (2000), in our model default arises as an equilibrium phenomenon, because agents choose what fraction to pay from their outstanding debt. However, unlike these authors, the cost of defaulting is not given by a penalty that reduces utility; instead, we have introduced default costs as penalties that reduce an individual's ability to borrow after he defaults on a loan. ${ }^{1}$

On the other hand, money is introduced via cash-in-advance constraints, whereby all commodities and assets can be traded only for money, and all asset deliveries are paid in money. Moreover, money enters the system as inside or outside money. Inside money enters the system accompanied by an offsetting obligation (money supplied by the Central Bank through Open Market Operations (OMOs) in the interbank market and matched by individual borrowers' debt obligation to commercial banks), while outside money enters the system free and clear of any offsetting obligations (monetary endowments).

\subsubsection{Outside Money}

Outside money proxies any liquid injection in the economy either from the government or the international economy. For example, if the government runs budget deficits then they manifest themselves as moneyfinanced fiscal transfers. Moreover, positive liquid wealth in the economy without any offsetting obligation anchors interest rates even in the absence of a Taylor Rule; otherwise, nominal interest rates in the absence of default would be zero, and therefore the price level of the economy indeterminate (see Buiter (1999), Dubey and Geanakoplos (2003), and Tsomocos (2008)).

Since outside money enters the system free and clear of any offsetting obligations, it is accumulated in the economy; therefore, we model an outside money shock as a perturbation to its growth rate.

$$
g_{G, t}=\frac{G_{t}}{G_{t-1}}
$$

where

$G_{t} \equiv$ outside money entering the economy in period $t$; i.e. aggregate monetary endowments:

$$
G_{t}=m_{t}^{\theta}+m_{t}^{\gamma}+m_{t}^{\psi}+m_{t}^{\delta}
$$

$m_{t}^{i} \equiv$ monetary endowments in period $t$ for $i=\{\theta, \gamma, \psi, \delta\}$

And the growth rate of $G_{t}$ follows and $\mathrm{AR}(1)$ process:

$$
\ln \left(g_{G, t}\right)=\rho^{G} \ln \left(\overline{g_{G}}\right)+\left(1-\rho^{G}\right) \ln \left(g_{G, t-1}\right)+e_{G, t} ; \quad e_{G, t} \sim N\left(0, \sigma_{G}^{2}\right)
$$

\footnotetext{
${ }^{1}$ Therefore, default penalties affect agents' financial constraints, not their objective functions.
} 
We also assume that outside money is always distributed to agents on the same 'pro-rata' basis. Therefore, households and banks always receive the same proportion of Government transfers. Assuming bank $\psi$, bank $\delta$, and the yeoman farmer $\gamma$ have a fraction $\omega_{1}, \omega_{2}$ and $\omega_{3}$ respectively of each period's outside money, it follows that:

$$
\begin{gathered}
m_{t}^{\psi}=\omega_{1} G_{t}, \text { where } \omega_{1}>0 \\
m_{t}^{\delta}=\omega_{2} G_{t} \text {, where } \omega_{2}>0 \\
m_{t}^{\gamma}=\omega_{3} G_{t}, \text { where } \omega_{3}>0 \\
m_{t}^{\theta}=\left(1-\omega_{1}-\omega_{2}-\omega_{3}\right) G_{t}, \text { where } 0<\omega_{1}+\omega_{2}+\omega_{3}<1
\end{gathered}
$$

Finally, since outside money is constantly growing, the system needs to be made stationary; following Schorfheide (2000) we achieve this by stationarizing the model with respect to $G_{t-1}$; i.e. we divide all the monetary variables at time $\mathrm{t}$ by $G_{t-1}$; thus all equations are re-specified in terms of the money growth rate and stationarized variables, which we denote with hats $\left(\hat{X}_{t}=X_{t} / G_{t-1}\right)$.

\subsubsection{Inside Money}

Inside money represents the interventions of the Central Bank in the interbank market; these liquidity injections must exit the system (with accrued interest and net of default) when borrowing commercial banks repay their obligations. Consequently, we model inside money shocks as changes to the level of expansionary $\mathrm{OMOs}^{2}$ :

$$
\hat{M}_{t}=\eta_{t}^{C B} \hat{\bar{M}}
$$

where

$$
\ln \left(\eta_{t}^{C B}\right)=\rho^{C B} \ln \left(\eta^{\bar{C} B}\right)+\left(1-\rho^{C B}\right) \ln \left(\eta_{t-1}^{C B}\right)+e_{C B, t} ; \quad e_{C B, t} \sim\left(0, \sigma_{C B}^{2}\right)
$$

and $\bar{\eta}^{C B}=1$ at the steady state of the economy.

\subsection{Household $\theta$ 's optimisation problem}

Household $\theta$ owns the banks, which have a 100 percent dividend payout ratio. $\theta$ receives its previous period deposits repayment, the banks' dividend payment, its labour income, purchases manufactured goods and makes deposits in bank $\psi$.

$$
\max _{\left\{d_{t}^{\theta}\right\},\left\{L_{t}^{\theta}\right\},\left\{b_{t}^{\theta}\right\}} E_{0} \sum_{t=0}^{\infty} \beta^{t} U\left(\frac{b_{t}^{\theta}}{p_{t}}\right)+\lambda U\left(N^{\theta}-L_{t}^{\theta}\right)
$$

s.t.

$b_{t}^{\theta}+d_{t}^{\theta} \leq m_{t}^{\theta}+w_{t}^{\theta} L_{t}^{\theta}+R_{t}^{d} d_{t-1}^{\theta}\left(1+r_{t-1}^{d}\right)+\pi_{t}^{\psi}+\pi_{t}^{\delta}, \quad \forall t \in T$

(i.e. goods expenditures + deposits at time $\mathrm{t} \leq$ private monetary endowments

+ labour income at time $t+$ deposits repayment + banks dividend payments)

\footnotetext{
${ }^{2}$ Since outside money is growing constantly, which requires the stationarization of all nominal variables in order to solve the model, we chose a specification for the inside money shock that represented a perturbation to the ratio of inside to outside money.
} 
where

$b_{t}^{\theta} \equiv$ amount of fiat money sent by $\theta$ to purchase goods at time $t$

$d_{t}^{\theta} \equiv$ deposits made by $\theta$ in bank $\psi$ at time $t$

$p_{t} \equiv$ price of consumption goods at time $t$

$N^{\theta} \equiv \theta$ 's time endowment

$L_{t}^{\theta} \equiv$ amount of time $\theta$ chooses to work in period $t$

$w_{t} \equiv$ wage rate paid per unit of time worked in period $t$

$R_{t}^{\theta} \equiv$ expected rate of delivery on deposits made in period $t-1$

$r_{t}^{d} \equiv$ interest rate of return on deposits in period $t$

$\pi_{t}^{\psi} \equiv$ bank $\psi$ 's profits in period $t$

$\pi_{t}^{\delta} \equiv$ bank $\delta$ 's profits in period $t$

$\beta \equiv$ discount factor

$\lambda \equiv$ leisure relative preference parameter

\subsubsection{Behaviour of Household $\theta$}

The maximisation of the objective function (10) subject to the budget constraint (11) with respect to expenditures in the goods market (or deposits) and labour, yields the following first-order conditions for consumption and leisure of $\theta$ respectively:

$$
\begin{gathered}
g_{G, t} U^{\prime}\left(c_{t}^{\theta}\right)=\beta E_{t}\left\{\frac{\left(1+r_{t}^{d}\right) R_{t+1}^{d}}{\hat{p}_{t+1} / \hat{p}_{t}} U^{\prime}\left(c_{t+1}^{\theta}\right)\right\} \\
\frac{\hat{w}_{t}}{\hat{p}_{t}}=\frac{U^{\prime}\left(N^{\theta}-L_{t}^{\theta}\right)}{U^{\prime}\left(c_{t}^{\theta}\right)}
\end{gathered}
$$

Equation (12) extends the usual Euler equation by taking into account the possibility of default on deposits $\left(R_{t+1}^{d}\right)$, and equation (13) depicts the traditional leisure-consumption trade-off.

Note that budget constraints for $\theta$ and the other agents of the economy bind, because money is fiat and agents do not derive utility from holding it. Thus, individuals do not hold idle cash, instead they lend it out to someone who needs it.

\subsection{Yeoman Farmer $(\gamma)$ 's optimisation problem}

$\gamma$ is a "yeoman farmer", who hires labour from $\theta$, then it manufactures goods, a fraction of which are consumed by himself, while the rest are sold to $\theta$.

$\gamma$ repays his previous period outstanding debt with the profits accumulated from the proceeds of last period sales. Furthermore, $\gamma$ takes out a loan with bank $\delta$ (net of the penalty costs from defaulting on his previous period loan), to pay for his expenses in the labour market.

We assume that $\gamma$ has the same discount factor as $\theta$.

$$
\max _{\left\{b_{L, t}^{\gamma}\right\},\left\{q_{t}^{\gamma}\right\},\left\{\mu_{t}^{\gamma}\right\},\left\{v_{t}^{F}\right\}} E_{0} \sum_{t=0}^{\infty} \beta^{t} U\left(Y_{t}^{\gamma}-q_{t}^{\gamma}\right)
$$

s.t.

$$
Y_{t}^{\gamma}=A_{t}\left(\frac{b_{L, t}^{\gamma}}{w_{t}}\right)^{\alpha} \quad \forall t \in T
$$




$$
v_{t}^{F} \mu_{t-1}^{\gamma} \leq m_{t}^{\gamma}+p_{t-1} q_{t-1}^{\gamma} \quad \forall t \in T \quad \text { with } \quad v_{0}^{F}=\mu_{-1}^{\gamma}=0
$$

i.e. corporate loan repayment at time $\mathrm{t} \leq$ private monetary endowments at time $\mathrm{t}$

+ sales revenues carried forward from period ( $t-1)$

$b_{L, t}^{\gamma} \leq \frac{\mu_{t}^{\gamma}}{\left(1+r_{t}^{F}\right)}-\tau_{t}^{\gamma}\left(1-v_{t}^{F}\right) \mu_{t-1}^{\gamma} \quad \forall t \in T \quad$ with $\quad v_{0}^{F}=\mu_{-1}^{\gamma}=0$

(i.e. payroll payment at time $\mathrm{t} \leq$ corporate borrowing at time $\mathrm{t}$ - credit costs on outstanding corporate debt)

At $t=0$ equations (5) and (6) become

$$
\begin{gathered}
b_{0} \leq m_{0}^{\gamma}+\frac{\mu_{0}^{\gamma}}{\left(1+r_{0}^{F}\right)}-\tau_{0}^{\gamma}\left(1-v_{0}^{F}\right) \mu_{-1}^{\gamma} \\
\ln \left(A_{t}\right)=\rho^{A} \ln (\bar{A})+\left(1-\rho^{A}\right) \ln \left(A_{t-1}\right)+e_{A, t} ; \quad e_{A, t} \sim N\left(0, \sigma_{A}^{2}\right) \\
\ln \left(\tau_{t}^{\gamma}\right)=\rho^{\gamma} \ln \left(\overline{\tau^{\gamma}}\right)+\left(1-\rho^{\gamma}\right) \ln \left(\tau_{t-1}^{\gamma}\right)+e_{\gamma, t} ; \quad e_{\gamma, t} N\left(0, \sigma_{\gamma}^{2}\right)
\end{gathered}
$$

Where

$Y_{t}^{\gamma} \equiv$ production of consumption goods by $\gamma$ in period $t$

$q_{t}^{\gamma} \equiv$ amount of goods offered for sale by $\gamma$ in period $t$

$\mu_{t}^{\gamma} \equiv$ corporate debt acquired by $\gamma$ in the corporate credit market in period $t$

$v_{t}^{F} \equiv \gamma^{\prime}$ s repayment rate on his outstanding debt in the corporate credit market in period $t$

$r_{t}^{F} \equiv$ interest rate on corporate loans extended in period $t$

$b_{L, t}^{\gamma} \equiv$ amount of fiat money sent by $\gamma$ to hire labour at time $t$

$A_{t} \equiv$ technological factor in period $t$, it's a stationary $\mathrm{AR}(1)$ process

$m_{t}^{\gamma} \equiv \gamma^{\prime}$ s monetary endowments in period $t$

$\tau_{t}^{\gamma} \equiv$ default penalty on corporate credit outstanding debt in period $t$

$\alpha \equiv$ returns to scale parameter

\subsubsection{Behaviour of Yeoman Farmer $\gamma$}

The maximisation of the objective function (14) subject to budget constraints (16) and (17) with respect to expenditure in the labour market and good sales, yields respectively the following first-order conditions:

$$
\begin{gathered}
g_{G, t} U^{\prime}\left(c_{t}^{\gamma}\right)=\beta E_{t}\left\{\frac{\left(1+r_{t}^{F}\right) \tau_{t+1}^{\gamma}}{\hat{w}_{t+1} / \hat{w}_{t}} U^{\prime}\left(c_{t+1}^{\gamma}\right)\right\} \\
\frac{\hat{w}_{t}\left(1+r_{t}^{F}\right)}{\hat{p}_{t}}=\frac{U^{\prime}\left(L_{t}^{\theta}\right)}{U^{\prime}\left(q_{t}^{\gamma}\right)}
\end{gathered}
$$

Equation (20) extends the usual Euler equation for a liquidity constrained agent by taking into account the default cost he bears (saves) if he increases (decreases) the value of his debt in the current period $\left(\tau_{t+1}^{\gamma}\right)$. On the other hand, equation (21) represents the trade-off between buying and selling different goods; it states that in equilibrium, the marginal rate of substitution between purchased and sold goods has to equal their relative prices after taking into account the cost of financing the purchase of leisure $\left(1+r_{t}^{F}\right)$. 


\subsection{Bank $\psi$ 's optimisation problem}

Bank $\psi$ is risk averse. It maximizes a concave function of its net end-of-period cash flows, which are given by the repayment of last period interbank loans less the bank's repayment of household $\theta^{\prime} s$ last period deposits. Moreover, the bank takes deposits from households (less the default penalty), and makes credit extensions in the interbank market.

$$
\max _{\left\{\mu_{t}^{d}\right\},\left\{d_{t}^{I B}\right\},\left\{v_{t}^{d}\right\},\left\{\pi_{t}^{\psi}\right\}} E_{0} \sum_{t=0}^{\infty} \hat{\beta}^{t} U\left(\pi_{t}^{\psi}\right)
$$

s.t.

$$
\begin{array}{r}
\pi_{t}^{\psi}=R_{t}^{I B}\left(1+r_{t-1}^{I B}\right) d_{t-1}^{I B}-v_{t}^{d} \mu_{t-1}^{d} \quad \forall t \in T \quad \text { with } \quad v_{0}^{d}=\mu_{-1}^{d}=d_{-1}^{I B}=0 \\
d_{t}^{I B} \leq m_{t}^{\psi}+\frac{\mu_{t}^{d}}{\left(1+r_{t}^{d}\right)}-\tau_{t}^{\psi}\left(1-v_{t}^{d}\right) \mu_{t-1}^{d} \quad \forall t \in T \quad \text { with } \quad v_{0}^{d}=\mu_{-1}^{d}=d_{-1}^{I B}=0
\end{array}
$$

(i.e. interbank credit extensions at time $\mathrm{t} \leq$ monetary endowments + household deposits - credit costs on outstanding debt with households at time t)

$$
\ln \left(\tau_{t}^{\psi}\right)=\rho^{\psi} \ln \left(\bar{\tau}^{\psi}\right)+\left(1-\rho^{\psi}\right) \ln \left(\tau_{t-1}^{\psi}\right)+e_{\psi, t} ; \quad e_{\psi, t} \sim N\left(0, \sigma_{\psi}^{2}\right)
$$

Where

$$
\hat{\beta}=\beta \frac{U^{\prime}\left(b_{t+1}^{\theta}\right)}{U^{\prime}\left(b_{t}^{\theta}\right)}
$$

$m_{t}^{\psi} \equiv$ bank $\psi$ 's monetary endowment at the beginning of period $t$

$\mu_{t}^{d} \equiv$ debt that bank $\psi$ acquires with household $\theta$ in period $t$

$R_{t}^{I B} \equiv$ expected rate of delivery on interbank loans extended in period $t-1$

$r_{t}^{I B} \equiv$ interest rate on interbank loans extended in period $t$

$d_{t}^{I B} \equiv$ deposits made by bank $\psi$ in the interbank market in period $t$

$v_{t}^{I B} \equiv \psi$ 's re-payment rate on its outstanding debt in the interbank market in period $t$

$\tau_{t}^{\psi} \equiv$ default penalty on deposits in period $t$

$\hat{\beta} \equiv$ banks' discount factor

\subsubsection{Behaviour of bank $\psi$}

The maximisation of the objective function (22) subject to budget constraints (23) and (24) with respect to borrowing from households and lending in the interbank market, yields respectively the following first-order conditions:

$$
\begin{gathered}
g_{G, t} \Pi^{\prime}\left(\hat{\pi}_{t}^{\psi}\right)=\beta\left(1+r_{t}^{d}\right) E_{t}\left\{\tau_{t+1}^{\psi} \Pi^{\prime}\left(\hat{\pi}_{t+1}^{\psi}\right)\right\} \\
g_{G, t} \Pi^{\prime}\left(\hat{\pi}_{t}^{\psi}\right)=\beta\left(1+r_{t}^{I B}\right) E_{t}\left\{R_{t+1}^{I B} \tau_{t+1}^{\psi} \Pi^{\prime}\left(\hat{\pi}_{t+1}^{\psi}\right)\right\}
\end{gathered}
$$


Equation (26) implies that in equilibrium, banks trade-off the benefits of additional future profits due to lower borrowing in the current period after taking account of interest and credit costs savings, with the costs of defaulting less on their current outstanding debt obligations with households. Note that in order to maintain its desired level of credit extension in the interbank market in the present, if bank $\psi$ borrows less from households, it must lower its credit costs by repaying a higher fraction on deposits, and thus lowering its profits, at that period.

Similarly, equation (27) implies that banks trade-off the benefits of additional future profits due to larger credit extensions in the interbank market in the present (taking account of accrued interest and default), with the costs the bank has to bear in order to make that additional credit extension; namely, the cost of higher borrowing (which entails a marginal increase of credit costs by $\tau_{t+1}^{\psi}$ ), and/or the cost of repaying a higher fraction of outstanding obligations today.

\subsection{Bank $\delta$ 's optimisation problem}

Bank $\delta$ is risk averse. It maximizes a concave function of its net end-of-period cash flows, which are given by the repayment of last period corporate loans less the bank's repayment of its interbank last period

outstanding debt. Moreover, the bank makes corporate credit extensions with the loan it takes out in the interbank market (less the default penalty).

$$
\max _{\left\{d_{t}^{F}\right\},\left\{\mu_{t}^{I B}\right\},\left\{v_{t}^{I B}\right\},\left\{\pi_{t}^{\delta}\right\}} E_{0} \sum_{t=0}^{\infty} \hat{\beta}^{t} U\left(\pi_{t}^{\delta}\right)
$$

s.t.

$$
\begin{gathered}
\pi_{t}^{\delta}=R_{t}^{F}\left(1+r_{t-1}^{F}\right) d_{t-1}^{F}-v_{t}^{I B} \mu_{t-1}^{I B} \quad \forall t \in T \quad \text { with } \quad v_{0}^{I B}=\mu_{-1}^{I B}=d_{-1}^{F}=0 \\
d_{t}^{F} \leq m_{t}^{\delta}+\frac{\mu_{t}^{I B}}{\left(1+r_{t}^{I B}\right)}-\tau_{t}^{\delta}\left(1-v_{t}^{I B}\right) \mu_{t-1}^{I B} \quad \forall t \in T \quad \text { with } \quad v_{0}^{I B}=\mu_{-1}^{I B}=d_{-1}^{F}=0
\end{gathered}
$$

(i.e. corporate credit extensions at time $\mathrm{t} \leq$ monetary endowments + interbank borrowing - credit

costs on outstanding interbank debt at time t)

$$
\ln \left(\tau_{t}^{\delta}\right)=\rho^{\delta} \ln \left(\overline{\tau^{\delta}}\right)+\left(1-\rho^{\delta}\right) \ln \left(\tau_{t-1}^{\delta}\right)+e_{\delta, t} ; \quad e_{\delta, t} \sim N\left(0, \sigma_{\delta}^{2}\right)
$$

Where

$m_{t}^{\delta} \equiv$ bank $\delta$ 's monetary endowment at the beginning of period $t$

$\mu_{t}^{I B} \equiv$ debt that bank $\delta$ acquires in the interbank market in period $t$

$R_{t}^{F} \equiv$ expected rate of delivery on corporate loans extended in period $t-1$

$r_{t}^{F} \equiv$ interest rate on corporate loans extended in period $t$

$d_{t}^{F} \equiv$ deposits made by bank $\delta$ in the corporate credit market in period $t$

$v_{t}^{F} \equiv \delta$ 's re-payment rate on its outstanding debt in the corporate credit market in period $t$

$\tau_{t}^{\psi} \equiv$ default penalty on deposits in period $t$

\subsubsection{Behaviour of bank $\delta$}

The maximisation of the objective function (28) subject to budget constraints (29) and (30) with respect to borrowing in the interbank market and credit extensions to yeoman farmer $\gamma$, yields respectively the following first-order conditions:

$$
g_{G, t} \Pi^{\prime}\left(\hat{\pi}_{t}^{\delta}\right)=\beta\left(1+r_{t}^{I B}\right) E_{t}\left\{\tau_{t+1}^{\delta} \Pi^{\prime}\left(\hat{\pi}_{t+1}^{\delta}\right)\right\}
$$




$$
g_{G, t} \Pi^{\prime}\left(\hat{\pi}_{t}^{\delta}\right)=\beta\left(1+r_{t}^{F}\right) E_{t}\left\{R_{t+1}^{F} \tau_{t+1}^{\delta} \Pi^{\prime}\left(\hat{\pi}_{t+1}^{\delta}\right)\right\}
$$

These equations can be interpreted similarly to the First Order Conditions of bank $\psi$, equations (26) and $(27)$.

\subsection{Market clearing conditions}

There are 5 markets in the economy: the goods, labour, consumer deposit, interbank, and corporate credit markets. In each of these markets the price equating demand and supply is determined.

Goods market. In every period, the goods market clears when the amount of money offered for goods is exchanged for the quantity of goods offered for sale. Thus, $\forall t \in T$, whenever $b_{t}^{\theta}>0$ and $q_{t}^{\gamma}>0$,

$$
\hat{p}_{t}=\frac{\hat{b}_{t}^{\theta}}{q_{t}^{\gamma}}
$$

Labour market. In every period, the labour market clears when labour expenditures by $\gamma$ are exchanged for the amount of hours that household $\theta$ is willing to work. Thus, $\forall t \in T$, whenever $b_{L, t}^{\gamma}>0$ and $L_{t}^{\theta}>0$,

$$
\hat{w}_{t}=\frac{\hat{b}_{L, t}^{\gamma}}{L_{t}^{\theta}}
$$

Deposit market. The consumer deposit market clears when the amount of money the commercial bank $\psi$ offers to repay in the next period is exchanged for the amount of money $\theta$ deposits in the current period. Thus, $\forall t \in T$, whenever $\mu_{t}^{d}>0$ and $d_{t}^{\theta}>0$,

$$
1+r_{t}^{d}=\frac{\hat{\mu}_{t}^{d}}{\hat{d}_{t}^{\theta}}
$$

Interbank market. The interbank market clears when the amount of money commercial bank $\delta$ promises to repay in the next period is exchanged for the credit extension commercial bank $\psi$ and the Central Bank offer in the current period. Thus, $\forall t \in T$, whenever $\mu_{t}^{I B}>0$ and $d_{t}^{I B}+M_{t}>0^{3}$,

$$
1+r_{t}^{I B}=\frac{\hat{\mu}_{t}^{I B}}{\hat{d}_{t}^{I B}+\hat{M}_{t}}
$$

Corporate credit market. The corporate credit market clears when the amount of yeoman farmer $\gamma$ offers to repay in the next period is exchanged for the credit extension commercial bank $\delta$ offers in the current period. Thus, $\forall t \in T$, whenever $\mu_{t}^{\gamma}>0$ and $d_{t}^{F}>0$,

$$
1+r_{t}^{F}=\frac{\hat{\mu}_{t}^{\gamma}}{\hat{d}_{t}^{F}}
$$

\subsection{Rational expectations}

Rational expectations conditions imply that households and commercial banks are correct in their expectations about the fraction of loans that will be repaid to them.

Bank $\delta$ 's expected rate of corporate loan delivery is given by

\footnotetext{
${ }^{3}$ In this setting, the Central Bank can control either $r_{t}^{I B}$ or $M_{t}$, but Goodhart et. al. (2008) show that the optimal monetary policy instrument is the interest rate.
} 


$$
R_{t}^{F}=\left\{\begin{array}{lll}
\frac{v_{t}^{F} \mu^{\gamma}}{\mu_{t}^{\gamma}}=v_{t}^{F} & \text { if } \quad \mu_{t}^{\gamma}>0 \\
\text { arbitrary } & \text { if } \quad \mu_{t}^{\gamma}=0
\end{array} \quad \forall t \in T\right.
$$

Bank $\psi$ 's expected rate of interbank loan delivery is given by

$$
R_{t}^{I B}=\left\{\begin{array}{lll}
\frac{v_{t}^{I B} \mu_{t}^{I B}}{\mu_{t}^{I B}}=v_{t}^{I B} & \text { if } \mu_{t}^{I B}>0 \\
\text { arbitrary } & \text { if } \mu_{t}^{I B}=0
\end{array} \quad \forall t \in T\right.
$$

Household $\theta$ 's expected rate of deposits delivery is given by

$$
R_{t}^{d}=\left\{\begin{array}{llc}
\frac{v_{t}^{d} \mu_{t}^{d}}{\mu_{t}^{d}}=v_{t}^{d} & \text { if } \quad \mu_{t}^{d}>0 \\
\text { arbitrary } & \text { if } \quad \mu_{t}^{d}=0
\end{array} \quad \forall t\right.
$$

\section{Equilibrium}

\subsection{Short Run Equilibrium Definition}

Let

$$
\begin{aligned}
\sigma^{\theta} & =\left\{d_{t}^{\theta}, L_{t}^{\theta}, b_{t}^{\theta}\right\}_{t}^{\infty} \\
\sigma^{\gamma} & =\left\{b_{L, t}^{\gamma}, q_{t}^{\gamma}, \mu_{t}^{\gamma}, v_{t}^{F}\right\}_{t}^{\infty} \\
\sigma^{\psi} & =\left\{\mu_{t}^{d}, d_{t}^{I B}, v_{t}^{d}, \pi_{t}^{\psi}\right\}_{t}^{\infty} \\
\sigma^{\delta} & =\left\{d_{t}^{F}, \mu_{t}^{I B}, v_{t}^{I B}, \pi_{t}^{\delta}\right\}_{t}^{\infty}
\end{aligned}
$$

Also, let the vector of macroeconomic variables be represented by

$$
\kappa=\left\{p_{t}, w_{t}, r_{t}^{d}, r_{t}^{I B}, r_{t}^{F}\right\}_{t}^{\infty}
$$

and the budget set of all agents denoted by

$$
\begin{aligned}
& B^{\theta}(\kappa)=\left\{\sigma^{\theta}:(2) \text { holds }\right\} \\
& B^{\gamma}(\kappa)=\left\{\sigma^{\gamma}:(6)-(7) \text { hold }\right\} \\
& B^{\psi}(\kappa)=\left\{\sigma^{\psi}:(11) \text { holds }\right\} \\
& B^{\delta}(\kappa)=\left\{\sigma^{\delta}:(15) \text { holds }\right\}
\end{aligned}
$$


Then $\left(\sigma^{\theta}, \sigma^{\gamma}, \sigma^{\psi}, \sigma^{\delta}, \kappa\right)$ is a monetary short run equilibrium with commercial banks, money, and default iff:

1. All agents optimize given their budget sets.
(a) $\sigma^{h} \in \arg \max _{\sigma^{h} \in B^{h}(\kappa)} U^{h}\left(\chi_{t}^{h}\right), \quad$ for $h \in H=\{\theta, \gamma\}, t \in T$
(b) $\sigma^{j} \in \arg \max _{\sigma^{j} \in B^{j}(\kappa)} \Pi^{j}\left(\chi_{t}^{j}\right), \quad$ for $\quad j \in J=\{\psi, \delta\}, t \in T$

Where $\chi_{t}^{h}$ is the vector of quantities of goods and leisure consumed by agent $h$ at time $t \in T, U^{h}($.$) is$ his utility function over consumption streams of goods and leisure, and $\Pi($.$) is the utility function of$ commercial banks over their profits.

2. All markets clear. Hence, equations (16) - (20) hold.

3. Expectations are rational. Thus, conditions (21) - (23) are satisfied.

\subsection{Long Run Equilibrium (Steady State) Definition}

In the steady state, in addition to the conditions required to obtain a Short Run Equilibrium:

1. All real and nominal (stationarised) variables do not grow, such that

$$
x_{t}=x \quad \forall t \in T \quad x_{t} \in X_{t}=\left\{\sigma^{\theta}, \sigma^{\gamma}, \sigma^{\psi}, \sigma^{\delta}, \kappa\right\}
$$

2. The economy is not subject to any current or expected shocks, such that

$$
e_{t}=0 \quad \forall t \in T \quad e_{t}=\left\{\epsilon_{t}^{\theta}, e_{A, t}, e_{G, t}, e_{C B, t}\right\}
$$

\subsection{Characterisation of the Equilibrium}

Put differently, our view is consistent with the long run money non-neutrality proposition as the Real Business Cycle (RBC) as well as the New Keynesian literature suggests. However, our model obtains money non-neutrality in the short-run unlike the RBC models where neutrality always holds. Furthermore, in stark difference with the New Keynesian approach where short run non-neutrality obtains only through real frictions such as monopolistic competition and asymmetric information, in our framework non-neutrality is driven by our postulated transaction technology and its subsequent transactions and investment demand for money. In other words, liquidity and default are arguably the driving forces of our results.

Steady State At the deterministic steady state, all real and nominal (stationarised) variables do not grow, outside money growth rate is constant, and the Central Bank does not change its monetary policy stance. The steady state of the model is obtained after imposing these conditions on the short run equilibrium solution. See the Appendix 1.

Proposition 3.1 At any short run equilibrium, $r_{t}^{d}, r_{t}^{I B} \geq 0$, and $r_{t}^{I B} \geq r_{t}^{d} \quad \forall t \in T$.

Proof The results follow from First Order Conditions (26) and (27)

$$
\left(1+r_{t}^{d}\right)=\left(1+r_{t}^{I B}\right) E_{t}\left\{R_{t+1}^{I B}\right\} \Rightarrow r_{t}^{I B} \geq r_{t}^{d}
$$

Proposition 3.2 At any short run equilibrium, $r_{t}^{I B}, r_{t}^{F} \geq 0$, and $r_{t}^{F} \geq r_{t}^{I B} \quad \forall t \in T$.

Proof The results follow from First Order Conditions (32) and (33)

$$
\left(1+r_{t}^{I B}\right)=\left(1+r_{t}^{F}\right) E_{t}\left\{R_{t+1}^{F}\right\} \Rightarrow r_{t}^{F} \geq r_{t}^{I B}
$$


Proposition 3.3 To preclude arbitrage opportunities in the steady state, $v^{d} \geq v^{I B} \geq v^{F} \Leftrightarrow r^{d} \leq r^{I B} \leq r^{F}$.

Proof The results follow immediately from the long run solution of the model and the conditions which ensure that agents do not repay more than what they owe, or that they are not rewarded for defaulting on their obligations (these are equivalent to the transversality conditions); in other words, agents are allowed to default partially. Consequently, endogenous default is compatible with the orderly functioning of the market economy.

$$
\begin{gathered}
\bar{\tau}^{\psi} \leq 1 \rightarrow v^{d}=\bar{\tau}^{\psi} \leq 1 \\
\bar{\tau}^{\delta} \leq \bar{\tau}^{\psi} \rightarrow v^{I B}=\frac{\bar{\tau}^{\delta}}{\bar{\tau}^{\psi}} \leq 1 \\
\bar{\tau}^{\gamma} \leq \bar{\tau}^{\delta} \rightarrow v^{F}=\frac{\bar{\tau}^{\gamma}}{\bar{\tau}^{\delta}} \leq 1
\end{gathered}
$$

Proposition 3.4 In the steady state, higher default penalties induce lower interest rates: the Default Penalty (Regulatory) Accelerator Principle

Proof The results follow immediately from the long run solution of the model:

$$
\begin{aligned}
& \left(1+r^{d}\right)=\frac{\bar{g}_{G}}{\beta \bar{\tau}^{\psi}} \\
& \left(1+r^{I B}\right)=\frac{\bar{g}_{G}}{\beta \bar{\tau}^{\delta}} \\
& \left(1+r^{F}\right)=\frac{\bar{g}_{G}}{\beta \bar{\tau} \gamma}
\end{aligned}
$$

Proposition 3.5 If $r_{t}^{F}>0$ for $t \in T$, then monetary and regulatory policy is non-neutral in the short run.

Proof Monetary and regulatory shocks, which affect the corporate credit rate, are non-neutral; otherwise, a contradiction between equations (13) and (21) (below) will emerge.

$$
\begin{gathered}
\frac{\hat{w}_{t}}{\hat{p}_{t}}=\frac{U^{\prime}\left(N^{\theta}-L_{t}^{\theta}\right)}{U^{\prime}\left(c_{t}^{\theta}\right)} \\
\frac{\hat{w}_{t}\left(1+r_{t}^{F}\right)}{\hat{p}_{t}}=\frac{U^{\prime}\left(L_{t}^{\theta}\right)}{U^{\prime}\left(q_{t}^{\gamma}\right)}
\end{gathered}
$$

Proposition 3.6 Fisher Effect: Nominal interest rates are approximately equal to real interest rates plus expected inflation and a risk premium.

Proof Suppose $b_{t}^{\theta}>0 \forall t \in T$ and that $\theta$ has money left over when the consumer deposit market meets at $\mathrm{t}$, then in the short-run equilibrium (from equation (12)):

$$
\left(1+r_{t}^{d}\right)=g_{G, t}\left(\frac{u^{\prime}\left(c_{t}^{\theta}\right)}{E_{t}\left\{u^{\prime}\left(c_{t+1}^{\theta}\right)\right\}}\right)\left(\frac{E_{t}\left\{\hat{p}_{t+1}\right\}}{\hat{p}_{t}}\right)\left(\frac{1}{R_{t+1}^{d}}\right) \Leftrightarrow r_{t}^{d} \approx \frac{u^{\prime}\left(c_{t}^{\theta}\right)}{E_{t}\left\{u^{\prime}\left(c_{t+1}^{\theta}\right)\right\}}+E_{t}\left\{\Pi_{t}^{g}+\log \left(\frac{g_{G, t}}{R_{t+1}^{d}}\right)\right\}
$$

Similarly, assume $b_{L, t}^{\gamma}>0 \forall t \in T$, and that $\gamma$ has money left over when the corporate loan comes due at $\mathrm{t}$, then in the short-run equilibrium (from equation (20))

$$
\left(1+r_{t}^{F}\right)=g_{G, t}\left(\frac{u^{\prime}\left(c_{t}^{\gamma}\right)}{E_{t}\left\{u^{\prime}\left(c_{t+1}^{\gamma}\right)\right\}}\right)\left(\frac{E_{t}\left\{\hat{w}_{t+1}\right\}}{\hat{w}_{t}}\right)\left(\frac{1}{\tau_{t+1}^{\gamma}}\right) \Leftrightarrow r_{t}^{F} \approx \frac{u^{\prime}\left(c_{t}^{\gamma}\right)}{E_{t}\left\{u^{\prime}\left(c_{t+1}^{\gamma}\right)\right\}}+E_{t}\left\{\Pi_{t}^{w}+\log \left(\frac{g_{G, t}}{\tau_{t+1}^{\gamma}}\right)\right\}
$$


Hereafter, we analyse a parameterized version of the model. Table 1 of Appendix 1 contains the chosen parameter values. ${ }^{4}$ Furthermore, steady state values for interest and repayment rates are calculated following propositions 3.1 and 3.2, whilst the steady state solution for the rest of the endogenous variables is obtained numerically (See Table 2 of Appendix 1).

\section{Simulations}

The purpose of this section is to describe how the endogenous variables of the model respond to several shocks, and to assess the impact of introducing agent heterogeneity, liquidity and default into a DSGE model. Therefore, we analyze the effects of shocks to the ratio of outside to inside money (monetary policy shock), the outside money growth rate (money-financed fiscal transfers or IS curve shock), and productivity in three different models. We also evaluate the impact of regulatory policy; however, these shocks have non-trivial effects only in the presence of default frictions.

The first model is a standard (representative agent) New Keynesian framework, which is described by three key equations; an aggregate demand equation (IS curve) whereby aggregate demand is related to future and/or lagged output and real interest rates (or real money balances); a Phillips Curve, which is derived from the optimization of price setting monopolistic firms, thereby relating inflation with current output and inflation expectations; and a monetary policy or Taylor rule; however, to compare the simulations of our model with the New Keynesian framework, we replace the Central Bank's reaction function with a stochastic process for the stock of money (see the New Keynesian Model section in the Appendix 1).

Using our framework, we derive the second and third models. First, we allow the model to overcome only two of the limitations of the New Keynesian framework by incorporating liquidity and agent heterogeneity (Monetary General Equilibrium Model without Default, MGE). In the third model we further relax the assumption of no default. ${ }^{5}$ The upshot of this framework is that the comprehensive analysis of monetary and financial stability policy depends crucially on the interplay of endogenous default, liquidity, heterogeneity, and more importantly, a non-trivial and active banking sector. It is the combination of these elements what allows for a systematic analysis of the short-run effects of exogenous shocks in capital markets and their consequent impact on the real economy.

The New Keynesian model does not include financial frictions, which implies that the interest rate is not determined in the money market. On the other hand, although the MGE model incorporates agent heterogeneity and liquidity, in absence of default, no arbitrage requires interest rates to be equal across all markets; thus net lending is constant, and profits in the banking sector are affected only by the interest rate.

\subsection{Inside Money Shock}

\subsubsection{Monetary Policy Shock in the New Keynesian Model}

An exogenous increase in the stock of money raises real money balances, and thus aggregate demand. A positive output gap inflates prices, thereby lowering real money balances, and hence demand. This implies that monetary policy is neutral in the long run, whereas in the short run sluggishly adjusting prices explain

\footnotetext{
${ }^{4}$ Note that this set of parameters was not obtained through a calibration exercise. We will calibrate the model in a future version of this paper.

${ }^{5}$ Previously, there have been attempts to include financial frictions in DSGE models, but none of them has successfully included all the elements that are essential to the analysis of financial stability, namely liquidity, default and agent heterogeneity. Leao and Leao (2007), include default but they ignore liquidity and agent heterogeneity, de Walque et. al (2008) include default and heterogeneity in the banking sector but they treat money as a veil, Iacoviello and Neri (2007) and Notarpietro (2007), have agent heterogeneity and a banking sector, but they do not incorporate default risk or liquidity, nor do they allow the banking sector to play an active role in the economy.
} 
the real effects of monetary policy as well as the gradual stabilization of output and inflation (See Figure 2 in Appendix 3).

\subsubsection{Monetary Policy Shock in a Monetary General Equilibrium Model without Default}

In the monetary model without default, a monetary policy shock (an increase in the ratio of inside to outside money) lowers the interbank rate, which induces bank $\delta$ to borrow more from bank $\psi$. To preclude arbitrage opportunities, the borrowing bank makes a larger credit extension in the corporate credit market, thereby reducing its interest rate until it reaches the interbank rate level.

Easier credit conditions allow the yeoman farmer $\gamma$ to spend more in the labour market, which raises employment as well as wages. Consequently, higher labour income induces household $\theta$ to spend more in the goods market and to make larger deposits, which increases trade and goods prices. Bank $\psi$ takes as many deposits from the household as required to lower the deposit rate to its non-arbitrage level.

Profitability in the banking sector drops due to the fall in interest rates, and welfare does not improve because trade increases more than output, thereby leaving the yeoman farmer $\gamma$ with a lower level of consumption. Finally as the monetary policy shock disappears, variables start reverting gradually to their steady state levels (see Figure 4 in Appendix 3).

\subsubsection{Monetary Policy Shock in a the presence of Liquidity, Agent Heterogeneity and Default}

An increase in the inside to outside money ratio reduces the interbank rate. Lower funding costs for bank $\delta$ allow him to make larger corporate credit extensions, thereby reducing the interest rate on corporate loans. This implies that yeoman farmer $\gamma$ can fund more spending in the labour market, which increases wages as well as the level of employment and output. Finally, as labour income increases, household $\theta$ spends more in the goods market and makes larger deposits with bank $\gamma$; this raises trade and prices and lowers the deposit rate.

As interest rates decrease, the relative cost of default falls; therefore, repayment rates drop across all credit markets except for the corporate credit market, where higher sales revenues induce $\gamma$ to repay a larger fraction of his outstanding corporate debt. Nevertheless, commercial banks profits rise because the negative effect of increased default is offset by the widening of credit spreads and higher lending.

In the period after the shock, higher goods sales revenues and wider credit spreads induce yeoman farmer $\gamma$ and bank $\delta$ to make larger repayments on their corporate and interbank obligations respectively. This is not the case for the deposit market, where due to the Central Bank's intervention, the volume of interbank lending relative to deposits decreases, thereby forcing bank $\psi$ to default more.

Higher default in the deposit market increases the deposit rate next period; this limits $\psi$ 's lending capacity in the interbank market which raises its interest rate. Tighter credit conditions for bank $\delta$, induce it make fewer credit extensions in the corporate credit market, thus increasing the corporate rate as well.

Consequently, the yeoman farmer $\gamma$ is forced to spend less in the labour market, thereby reducing employment and wages. This lowers household $\theta$ 's labour income, which induces him to spend less in the goods market and to make fewer deposits; thus, $\gamma$ 's revenues decrease and the deposit rate rises. As credit costs increase, default recovers in the interbank and deposit markets, whereas falling sales revenues induce $\gamma$ to gradually reduce the repayment rate on his corporate debt. 
As the monetary policy shock winds down, the stabilization process described in the previous two paragraphs helps the economy revert to its steady state level at a faster pace than in the absence of default (see Figures 5 and 6 in Appendix 3).

\subsubsection{Remarks}

In the presence of default, as aggregate repayment rates drop initially, interest rates start rising faster than in the MGE model; this explains why variables oscillate around the steady state as the effects of the shock disappear, as well as the fact that the economy undergoes a recession and becomes financially unstable ${ }^{6}$ a few periods after the shock. These medium term effects are overlooked by models that exclude financial frictions, especially default risk.

\subsection{Outside Money Shock}

\subsubsection{Fiscal Policy (IS Curve) Shock in the New Keynesian Model}

In the New Keynesian model, a fiscal expansion increases aggregate demand and therefore makes the output gap positive. Therefore, prices start to rise sluggishly, which lowers real money balances and the output gap. As the effects of the aggregate demand shock vanishes, output and prices return to their steady state levels; however, the economy undergoes a recession in the medium term because prices remain high for a few periods after the shock has disappeared completely (see Figure 7 in Appendix 3).

\subsubsection{Fiscal Policy Shock in a Monetary General Equilibrium Model without Default}

An exogenous increase in the growth rate of outside money raises the capacity of agents to make interest payments, thereby stimulating the demand for credit. Accordingly, to preclude arbitrage opportunities creditors make larger credit extensions to the extent that induces interest rates to rise equally .

On the other hand, larger monetary endowments provide incentives to the yeoman farmer to sell fewer goods because he requires fewer revenues to meet his desired level of spending in the labour market. Therefore, goods prices increase, which induces household $\theta$ to spend less in the goods market. Consequently, yeoman farmer $\gamma$ cuts production and demands less labour, which reduces wages. Higher prices and lower labour income force household $\theta$ to make fewer deposits with bank $\psi$ in order to smooth consumption.

This increases the deposit rate, and hence forces banks to make fewer credit extensions, thereby raising interbank and corporate credit rates until they reach their non-arbitrage levels. After the first period, since interest rates remain high, credit and spending keep falling, which reduces prices; nevertheless, this does not stimulate spending in the goods and labour markets because the effect of tighter credit conditions dominates.

Profits in the banking sector increase due to higher interest rates, while welfare does not improve because lower trade has a significant negative impact on $\theta$ 's consumption.

Finally, when the effects of the shock disappear, interest rates start to drop gradually, thereby stimulating credit, spending, and employment, which raise prices and wages. Thereafter, all variables return slowly to their steady state levels (see Figures 8 and 9 in Appendix 3).

\footnotetext{
${ }^{6}$ Hereafter, we will use the Goodhart-Tsomocos (2006) measure Financial Stability. According to these authors, an economy is financially unstable whenever substantial default of a 'number' of households and banks occurs, and the aggregate profitability of the banking sector decreases significantly.
} 


\subsubsection{Fiscal Policy Shock in a the presence of Liquidity, Agent Heterogeneity and Default}

The effects of an increase in the growth rate of outside money are qualitatively similar to those of the MGE model. As the capacity of agents to make interest payments increases, demand for credit and interest rates rise. Also, the yeoman farmer has incentives to sell fewer goods, which increases goods prices and induces household $\theta$ to spend less in the goods market. This lowers demand for labour, and hence wages. Higher prices and lower labour income force household $\theta$ to make fewer deposits with bank $\psi$, thereby increasing the deposit rate as well.

Nevertheless, interest rates increase more than in the MGE model because growth of money-financed fiscal transfers allow agents to afford larger credit costs, and thus to default more. Higher interest rates reduce demand for credit in the following period, and thus spending and employment decrease.

Lower repayment rates exacerbate the effects of fiscal policy on interest rates (relative to the default-free case); therefore, before the fiscal shock disappears, interest rates start to fall because credit costs reach a very high level, which induces agents to repay a larger fraction of their outstanding obligations.

When the effects of the shock vanish, repayment rates, trade and spending continue growing until once again credit costs reach a level that induces agents to default more. Afterwards, all variables move gradually towards their steady state level (see Figures 10 in Appendix 3).

\subsubsection{Remarks}

In the New Keynesian model a fiscal expansion increases output because the model relies on the assumption that aggregate demand is equal to consumption demand. In contrast, the models with monetary frictions and heterogeneous agents suggest that expansionary fiscal policy reduces output via a crowding-out effect (in line with the IS-LM model predictions); therefore, the producer's welfare improves at the expense of the household.

Moreover, the behaviour of default rates and their impact on interest rates, explains why the effects of fiscal policy are more pronounced than in the default-free frameworks, as well as why variables oscillate around their steady state levels when the effects of the shock start to disappear.

Finally, our model predicts that expansionary fiscal policy induces a deep recession in the short run, and that the economy becomes financially unstable in the short to medium run because aggregate default remains high and profitability in the banking sector starts to fall. These effects are not depicted by the models that exclude default frictions.

\subsection{Productivity Shock}

\subsubsection{Productivity Shock in the New Keynesian Model}

In the New Keynesian framework, a positive productivity shock reduces prices, which increases real balances and hence aggregate demand; however, a positive output gap increases the level of prices and inflation, thereby lowering real money balances and income. Since prices adjust sluggishly this stabilization process is smooth; thus as the effects of the productivity shock disappear, prices and output revert to their steady state levels gradually (See Figure 11 in Appendix 3).

\subsubsection{Productivity Shock in a Monetary General Equilibrium Model without Default}

A positive productivity shock increases the technological factor of production, $A_{t}$; hence yeoman farmer $\gamma$ produces more goods with the same amount labour. A higher supply of goods reduces prices, thus increasing 
trade by a smaller amount than output and raising consumption of both, $\theta$ and $\gamma$. Although, lower prices increase real wages, household $\theta$ does not change his supply of labour because he has a separable logarithmic utility function, which implies that in the absence of default, income and substitution effects offset each other. As the effects of the shock start to wind down, trade and prices return gradually to their steady state levels (see Figure 12 of the Appendix 3).

\subsubsection{Productivity Shock in a the presence of Liquidity, Agent Heterogeneity and Default}

A positive productivity shock increases the technological factor of production, $A_{t}$, which implies that the yeoman farmer can produce more goods with the same or fewer hours of work. As in the previous model, $\gamma$ supplies more goods, which drives prices down and increases consumption of both agents.

Lower prices reduce $\gamma$ 's revenues, thereby inducing the yeoman farmer to repay a lower fraction of his outstanding debt, and consequently lowering bank $\delta$ 's profits. Higher default in the corporate credit market raises $\gamma$ 's credit costs, thus forcing him to borrow more in order to satisfy his desired level of spending in the labour market. Higher demand for loans in the corporate credit market provide incentives to bank $\delta$ to borrow more and to repay a higher rate on its interbank debt. This lowers the interbank rate as well as $\delta$ 's credit costs.

Similarly, to meet its increased demand for interbank credit, bank $\psi$ takes more deposits from household $\theta$ and makes higher repayments. Consequently, and in stark contrast to the MGE model, household $\theta$ works more in order to satisfy the increased demand for deposits, but he distributes his additional labour income between deposits and goods expenditures to prevent the Marginal Rate of Substitution (MRS) of leisure over consumption to fall below its optimal level.

Thus, the supply of deposits becomes relatively 'scarce', which increases the deposit rate. On the other hand, the corporate credit interest rate falls because a lower interbank rate eases credit conditions for bank $\delta$, thereby allowing it to make larger credit extensions to the yeoman farmer. This implies that aggregate profitability in the banking sector falls; bank $\delta$ 's profits fall because wider corporate interbank-credit spreads cannot offset the negative effects of higher default in the corporate credit market, whereas bank $\psi$ 's profits drop as the spread between interbank and deposit rates narrows.

All variables begin reverting to their steady state levels as the technological shock starts to wind down. When prices start increasing, household $\theta$ reduces its spending in the goods market and trade falls; however, since real wages remains high, $\theta$ increases his supply of labour for a few periods. Once the productivity shock vanishes completely, as the level of employment is still high, yeoman farmer $\gamma$ sells fewer goods and demands less labour in order to improve his profits. This drives prices up and wages down, thereby forcing household $\theta$ to make fewer deposits and increasing the deposit rate. Tighter financial conditions in the deposit market induce agents to borrow less in the interbank and corporate credit markets, thereby raising their corresponding interest rates. Moreover, as $\gamma$ 's revenues improve, default in corporate loans falls, which in addition to higher interest rates, induces banks to default more on their obligations.

A positive productivity shock improves welfare of both, $\theta$ and $\gamma$ by increasing their levels of consumption, as explained previously. Moreover, the economy becomes financially unstable in the short run, where profits in the banking sector drop and default in the corporate market increases.

\subsubsection{Remarks}

The models that do not incorporate financial frictions, most importantly default, overlook the effects of productivity shocks on nominal and real variables except for prices and consumption. Moreover, our results suggest that a model without default frictions cannot predict the negative effects of technological shocks on financial stability in the short run. 


\subsection{Tighter Regulation}

In this section we assess the effects of a transitory tightening of financial regulation in financial markets. Higher default penalties increase credit costs, thereby inducing the yeoman farmer and commercial banks to repay a larger fraction of their outstanding obligations. Lower default reduces interest rates across all markets, thereby stimulating demand for credit. This increases the level of spending in the labour market, which raises employment and wages, and hence the levels of spending and trade in the goods markets.

Since default penalties increase in proportion to their initial level, credit costs increase more in the deposit market, followed by the interbank market and then the corporate credit market. Thus, the demand for deposits increases more than the demand for interbank credit, which in turn increases more than corporate credit demand. Consequently, credit spreads narrow, thereby reducing profits in the banking sector.

The economy maintains this trend for a few periods, but as the effects of tighter regulation start to disappear, credit costs fall below a threshold which induces agents to start repaying a lower fraction of their outstanding obligations. Nevertheless, since aggregate default remains relatively low, lending continues to grow, thereby maintaining interest rates low. When the effects of regulation vanish completely, the economy converges towards its steady state as interest rates start increasing in response to higher default, and tighter financial conditions reduce borrowing and spending.

The small differences between the dynamics of repayment rates are due to the fact that a proportional increase of default penalties has larger and more persistent effects on markets that are more heavily regulated in the steady state (the deposit market).

This policy reduces aggregate default in the short run, and promotes financial stability in the medium run, where aggregate default remains low and profits in the banking recover sharply.

\subsubsection{Remarks}

Effects of regulatory policy can only be assessed in a model that allows for default to arise as an equilibrium outcome. Moreover, due to agent heterogeneity, the effects of regulatory policies depend on the particular agent, or part of the economy, directly affected. This is due to the fact that the distribution of income and welfare between agents is affected differently (Goodhart 2004).

For this reason, we also analyze the effects of increasing the default penalty for one credit market at a time. Our results show that the agent directly affected by the regulatory change starts to behave more prudently, as well as the agents whose access to funding depends on the affected agent; therefore, tighter regulation in the corporate market increases repayment rates across all credit markets, in the interbank market it reduces default in the interbank and deposit markets only, and in the deposit market it only succeeds in raising repayment rates in that market.

Moreover, all though trade increases as a response to stricter regulation in any of the credit markets, the agent directly affected by the policy is worst off in the short run. For instance, higher default penalties in the interbank market reduce bank $\delta$ 's profits, but the household's welfare and the profitability of the other bank improve.

\section{Concluding Remarks}

We have proposed a model that, by including default frictions, liquidity and agent heterogeneity overcomes some of the limitations that the canonical DSGE has as a tool for the analysis of financial stability. To analyze the role of these frictions, we compared the effects of several types of shocks across three different models: a 
standard New Keynesian model, a model with money and heterogeneous agents but no default, and a model that incorporates all the aforementioned frictions.

Our results suggest that agent heterogeneity is essential to assess the welfare effects of exogenous shocks, because these depend on the part of the economy directly affected. Furthermore, unlike the New Keynesian framework, in the models that incorporate financial frictions such as liquidity, interest rates are determined in the credit and money markets and the price level of the economy is determinate.

The simulations also suggest that in the absence of default frictions, interest rates in the economy are equal to each other and the transmission mechanism of shocks, as well as their propagation is distorted. This implies that the short to medium run (adverse) effects that demand as well as supply shocks have on economic growth and financial stability are not properly captured.

This model and its results are a stepping-stone of our continuing research. We have abstracted from modelling a sophisticated production sector, as well as the reaction function of policy makers, in particular the Central Bank. Nevertheless, our model can be used to make these extensions, but these will be presented in future studies.

\section{References}

[1] Bernanke, B., M. Gertler, and S. Gilchrist (1999), 'The Financial Accelerator in a Quantitative Business Cycle Framework' in J. Taylor and M. Woodford (eds) Handbook of Macroeconomics, Volume 1C, North Holland.

[2] Buiter,W. H. (1999), 'The Fallacy of the Fiscal Theory of the Price Level', NBER Working Paper No. 7302.

[3] Curdia, V. and Woodford, M. 2009, 'Credit Spreads and Monetary Policy', NBER Working Paper No. 15289 .

[4] Dubey, P., and J. Geanakoplos, (2003), 'Real Determinacy with Nominal Assets', Cowles Foundation Discussion Paper No. $142 \%$.

[5] Goodhart CAE, P. Sunirand P. and D. Tsomocos, (2004), 'A Model to Analyse Financial Fragility: Applications', Journal of Financial Stability, 1, pp. 1-30.

[6] Goodhart CAE, P. Sunirand P. and D. Tsomocos, (2006), 'A Model to Analyse Financial Fragility', Economic Theory (27), pp. 107-142.

[7] Goodhart CAE, P. Sunirand P. and D. Tsomocos, (2008), 'The Optimal Monetary Instrument for Prudential Purposes' Journal of Financial Stability, forthcoming.

[8] Goodhart CAE, D. Tsomocos and A. Vardoulakis, (2009), 'Modelling a Housing and Mortgage Crisis', in Financial Stability, Monetary Policy and Central Banking. Edited by C. Echavarria, R. Fuentes and D. Gray, Series on Central Banking, Analysis and Economics Policies, Central Bank of Chile, forthcoming, 2009.

[9] Iacoviello, M. and S. Neri, (2007), 'Housing Markets Spillovers: Evidence from an Estimated DSGE Model'. Working Paper 659, Boston College Department of Economics.

[10] Kiyotaki N. and J. Moore, (2007), 'Credit Cycles'., Journal of Political Economy, 105, pp. 211-248.

[11] Leao E., and P. Leao, (2007), 'Modelling the central bank repo rate in a dynamic general equilibrium framework.', Economic Modelling,24, pp. 571-610. 
[12] Notarpietro, A., (2007), 'Credit Frictions and Household Debt in the US Business Cycle: A Bayesian Approach,', . Working Paper Universit Bocconi.

[13] Schorfheide, F. (2000), 'Loss function-based evaluation of DSGE models', Journal of Applied Econometrics, 15(6), 645-670.

[14] Tsomocos, D.P., (2003), 'Equilibrium Analysis, Banking and Financial Instability', Journal of Mathematical Economics, 39 (5), pp. 619-655.

[15] Tsomocos, D.P., (2008), 'Generic Determinacy and Money Non-neutrality of International Monetary Equilibria', Journal of Mathematical Economics, 44, pp. 866-887.

[16] de Walque, G., O. Pierrard y A. Rouabah, (2008), 'Financial (in)stability, supervision, and liquidity injections: a dynamic general equilibrium approach', Working Paper Research 148, National Bank of Belgium.

[17] Woodford, M. 2003. Interest and Prices: Foundations of a Theory of Monetary Policy, Princeton, NJ, Princeton University Press. 


\section{Appendix 1}

\section{First Order Conditions}

\section{Household $\theta$}

We assume that household $\theta$ derives logarithmic utility from his consumption of goods and leisure; thus his first order conditions are given by:

$$
\begin{gathered}
\frac{1}{p_{t} c_{t}^{\theta}}=\beta\left(1+r_{t}^{d}\right) E_{t}\left\{\frac{v_{t+1}^{d}}{p_{t+1} c_{t+1}^{\theta}}\right\} \Longleftrightarrow \frac{g_{G, t}}{\hat{p}_{t} c_{t}^{\theta}}=\beta\left(1+r_{t}^{d}\right) E_{t}\left\{\frac{v_{t+1}^{d}}{\hat{p}_{t+1} c_{t+1}^{\theta}}\right\} \\
\frac{w_{t}}{p_{t} c_{t}^{\theta}}=\frac{\lambda}{N^{\theta}-L_{t}^{\theta}} \Longleftrightarrow \frac{\hat{w}_{t}}{\hat{p}_{t} c_{t}^{\theta}}=\frac{\lambda}{N^{\theta}-L_{t}^{\theta}} \\
p_{t} c_{t}^{\theta}=w_{t} L_{t}^{\theta}+v_{t}^{d}\left(1+r_{t-1}^{d}\right) d_{t-1}^{\theta}-d_{t}^{\theta}+\pi_{t}^{\psi}+\pi_{t}^{\delta}+m_{t}^{\theta} \Longleftrightarrow \\
\hat{p}_{t} c_{t}^{\theta}=\hat{w}_{t} L_{t}^{\theta}-\hat{d}_{t}^{\theta}+\frac{v_{t}^{d}\left(1+r_{t-1}^{d}\right) \hat{d}_{t-1}^{\theta}}{g_{G, t-1}}+\hat{\pi}_{t}^{\psi}+\hat{\pi}_{t}^{\delta}+\left(1-\sum_{j=1}^{3} \omega_{j}\right) g_{G, t}
\end{gathered}
$$

\section{Yeoman Farmer $\gamma$}

We assume that yeoman farmer $\gamma$ derives logarithmic utility from his consumption of goods; thus his first order conditions are given by:

$$
\begin{gathered}
\frac{A_{t} L_{t}^{\alpha-1}}{\left(A_{t} L_{t}^{\theta}-q_{t}^{\gamma}\right) w_{t}}=\beta\left(1+r_{t}^{F}\right) E_{t}\left\{\frac{A_{t+1} L_{t+1}^{\alpha-1}}{\left(A_{t+1} L_{t+1}^{\theta}-q_{t+1}^{\gamma}\right)} \frac{\tau_{t+1}^{\gamma}}{w_{t+1}}\right\} \Longleftrightarrow \\
\frac{A_{t} L_{t}^{\alpha-1}}{\left(A_{t} L_{t}^{\theta}-q_{t}^{\gamma}\right)} \frac{g_{G, t}}{\hat{w}_{t}}=\beta\left(1+r_{t}^{F}\right) E_{t}\left\{\frac{A_{t+1} L_{t+1}^{\alpha-1}}{\left(A_{t+1} L_{t+1}^{\theta}-q_{t+1}^{\gamma}\right)} \frac{\tau_{t+1}^{\gamma}}{\hat{w}_{t+1}}\right\} \\
\frac{w_{t}\left(1+r_{t}^{F}\right)}{p_{t}}=\alpha A_{t} L_{t}^{\alpha-1} \Longleftrightarrow \frac{\hat{w}_{t}\left(1+r_{t}^{F}\right)}{\hat{p}_{t}}=\alpha A_{t} L_{t}^{\alpha-1} \\
m_{t}^{\gamma}+p_{t-1} q_{t-1}^{\gamma}=\left(1+r_{t-1}^{F}\right) d_{t-1}^{F} v_{t}^{F} \Longleftrightarrow \omega_{3} g_{G, t}+\hat{p}_{t-1} q_{t-1}^{\gamma}=\left(1+r_{t-1}^{F}\right) \hat{d}_{t-1}^{F} v_{t}^{F} \\
d_{t}^{F}-\tau_{t}^{\gamma}\left(1-v_{t}^{F}\right)\left(1+r_{t-1}^{F}\right) d_{t-1}^{F}=w_{t} L_{t}^{\theta} \Longleftrightarrow \\
\hat{d}_{t}^{F}-\frac{\tau_{t}^{\gamma}\left(1-v_{t}^{F}\right)\left(1+r_{t-1}^{F}\right) \hat{d}_{t-1}^{F}}{g_{G, t-1}}=\hat{w}_{t} L_{t}^{\theta}
\end{gathered}
$$

\section{Commercial Bank $\psi$}


We assume that commercial bank $\psi$ derives logarithmic utility from its profits; thus, his first order conditions are given by:

$$
\begin{gathered}
\frac{1}{\pi_{t}^{\psi}}=\beta\left(1+r_{t}^{d}\right) E_{t}\left\{\frac{\tau_{t+1}^{\psi}}{\pi_{t+1}^{\psi}}\right\} \Longleftrightarrow \frac{g_{G, t}}{\hat{\pi}_{t}^{\psi}}=\beta\left(1+r_{t}^{d}\right) E_{t}\left\{\frac{\tau_{t+1}^{\psi}}{\hat{\pi}_{t+1}^{\psi}}\right\} \\
\frac{1}{\pi_{t}^{\psi}}=\beta\left(1+r_{t}^{I B}\right) E_{t}\left\{\frac{\tau_{t+1}^{\psi} v_{t+1}^{I B}}{\pi_{t+1}^{\psi}}\right\} \Longleftrightarrow \frac{g_{G, t}}{\hat{\pi}_{t}^{\psi}}=\beta\left(1+r_{t}^{I B}\right) E_{t}\left\{\frac{\tau_{t+1}^{\psi} v_{t+1}^{I B}}{\hat{\pi}_{t+1}^{\psi}}\right\} \\
\pi_{t}^{\psi}=v_{t}^{I B}\left(1+r_{t-1}^{I B}\right) d_{t-1}^{I B}-v_{t}^{d} d_{t-1}^{\theta}\left(1+r_{t-1}^{d}\right) \Longleftrightarrow \\
\hat{\pi}_{t}^{\psi}=\frac{v_{t}^{I B}\left(1+r_{t-1}^{I B}\right) \hat{d}_{t-1}^{I B}-v_{t}^{d} \hat{d}_{t-1}^{\theta}\left(1+r_{t-1}^{d}\right)}{g_{G, t-1}} \\
m_{t}^{\psi}+d_{t}^{\theta}=\tau_{t}^{\psi}\left(1-v_{t}^{d}\right)\left(1+r_{t-1}^{d}\right) d_{t-1}^{\theta}+d_{t}^{I B} \Longleftrightarrow \\
\omega_{1} g_{G, t}+\hat{d}_{t}^{\theta}=\frac{\tau_{t}^{\psi}\left(1-v_{t}^{d}\right)\left(1+r_{t-1}^{d}\right) \hat{d}_{t-1}^{\theta}}{g_{G, t-1}}+\hat{d}_{t}^{I B}
\end{gathered}
$$

\section{Commercial Bank $\delta$}

We assume that commercial bank $\delta$ derives logarithmic utility from its profits; thus, his first order conditions are given by:

$$
\begin{gathered}
\frac{1}{\pi_{t}^{\delta}}=\beta\left(1+r_{t}^{F}\right) E_{t}\left\{\frac{\tau_{t+1}^{\delta} v_{t+1}^{F}}{\pi_{t+1}^{\delta}}\right\} \Longleftrightarrow \frac{g_{G, t}}{\hat{\pi}_{t}^{\delta}}=\beta\left(1+r_{t}^{F}\right) E_{t}\left\{\frac{\tau_{t+1}^{\delta} v_{t+1}^{F}}{\hat{\pi}_{t+1}^{F}}\right\} \\
\frac{1}{\pi_{t}^{\delta}}=\beta\left(1+r_{t}^{I B}\right) E_{t}\left\{\frac{\tau_{t+1}^{\delta}}{\pi_{t+1}^{\delta}}\right\} \Longleftrightarrow \frac{g_{G, t}}{\hat{\pi}_{t}^{\delta}}=\beta\left(1+r_{t}^{I B}\right) E_{t}\left\{\frac{\tau_{t+1}^{\delta}}{\hat{\pi}_{t+1}^{\delta}}\right\} \\
\pi_{t}^{\delta}=v_{t}^{F}\left(1+r_{t-1}^{F}\right) d_{t-1}^{F}-v_{t}^{I B}\left(1+r_{t-1}^{I B}\right)\left(d_{t-1}^{I B}+M_{t-1}\right) \Longleftrightarrow \\
\hat{\pi}_{t}^{\delta}=\frac{v_{t}^{F}\left(1+r_{t-1}^{F}\right) \hat{d}_{t-1}^{F}-v_{t}^{I B}\left(1+r_{t-1}^{I B}\right)\left(\hat{d}_{t-1}^{I B}+\hat{M}_{t-1}\right)}{g_{G, t-1}} \\
m_{t}^{\delta}+\left(d_{t}^{I B}+M_{t}\right)-\tau_{t}^{\delta}\left(1-v_{t}^{I B}\right)\left(1+r_{t-1}^{I B}\right)\left(d_{t-1}^{I B}+M_{t-1}\right)=d_{t}^{F} \Longleftrightarrow \\
\omega_{2} g_{G, t}+\left(\hat{d}_{t}^{I B}+\hat{M}_{t}\right)-\frac{\tau_{t}^{\delta}\left(1-v_{t}^{I B}\right)\left(1+r_{t-1}^{I B}\right)\left(\hat{d}_{t-1}^{I B}+\hat{M}_{t-1}\right)}{g_{G, t-1}}=\hat{d}_{t}^{F}
\end{gathered}
$$

\section{Steady State Solution}

\section{Household $\theta$}

$$
\begin{gathered}
\bar{g}_{G}=\beta\left(1+r^{d}\right) v^{d} \\
\frac{w}{p c^{\theta}}=\frac{\lambda}{N^{\theta}-L^{\theta}}
\end{gathered}
$$




$$
p c^{\theta}=\left(1-\sum_{j=1}^{3} \omega_{j}\right) \overline{g_{G}}+w L^{\theta}+\left(\frac{\left(1+r^{d}\right) v^{d}}{\bar{g}_{G}}-1\right) d^{\theta}+\frac{\left(\pi^{\psi}+\pi \delta\right)}{\bar{g}_{G}}
$$

Yeoman Farmer $\gamma$

$$
\begin{gathered}
\bar{g}_{G}=\beta\left(1+r^{F}\right) \tau^{\gamma} \\
\frac{w}{p}=\alpha \frac{\bar{A} L^{\alpha-1}}{1+r^{F}} \\
p c^{\theta}=v^{F}\left(1+r^{F}\right) d^{F} \\
d^{F}\left(1-\frac{\tau^{\gamma}\left(1-v^{F}\right)\left(1+r^{F}\right)}{\bar{g}_{G}}\right)=w L^{\theta}
\end{gathered}
$$

\section{Commercial Bank $\psi$}

$$
\begin{gathered}
\bar{g}_{G}=\beta\left(1+r^{d}\right) \tau^{\psi} \\
\bar{g}_{G}=\beta\left(1+r^{I B}\right) v^{I B} \tau^{\psi} \\
\omega_{1} \overline{g_{G}}+d^{\theta}\left(1-\frac{\tau^{\psi}\left(1-v^{d}\right)\left(1+r^{d}\right)}{\bar{g}_{G}}\right)=d^{I B} \\
\bar{g}_{M} \pi^{\psi}=v^{I B}\left(1+r^{I B}\right) d^{I B}-\left(1+r^{d}\right) v^{d} d^{\theta}
\end{gathered}
$$

\section{Commercial Bank $\delta$}

$$
\begin{gathered}
\bar{g}_{G}=\beta\left(1+r^{I B}\right) \tau^{\delta} \\
\bar{g}_{G}=\beta\left(1+r^{F}\right) v^{F} \tau^{\delta} \\
\omega_{2}{\overline{g_{G}}}+\left(d^{I B}+\hat{g}_{G}-1\right)\left(1-\frac{\tau^{\delta}\left(1-v^{I B}\right)\left(1+r^{I B}\right)}{\bar{g}_{G}}\right)=d^{F} \\
\bar{g}_{G} \pi^{\delta}=v^{F}\left(1+r^{F}\right) d^{F}-\left(1+r^{I B}\right) v^{I B}\left(d^{I B}+\hat{g}_{G}-1\right)
\end{gathered}
$$

\section{Outside Money Growth Rate}

$$
g_{G}=\overline{g_{G}}
$$




\section{Numerical Example}

Table 1: Parameters

\begin{tabular}{cccc}
\hline \hline Parameter & Value & Parameter & Value \\
\hline & & & \\
$\alpha$ & 1 & $\tau^{\psi}$ & 0.99 \\
$\bar{A}$ & 1 & $N^{\theta}$ & 1 \\
$\beta$ & 0.99 & $\omega_{1}$ & 0.25 \\
$\overline{g_{G}}$ & 1.03 & $\omega_{2}$ & 0.25 \\
$\rho$ & 0.7 & $\omega_{3}$ & 0.25 \\
$\tau^{\gamma}$ & 0.94 & $\hat{M}$ & 1 \\
$\tau^{\delta}$ & 0.97 & $\lambda$ & 1 \\
\hline
\end{tabular}

Table 2: Steady State

\begin{tabular}{cccc}
\hline \hline Variable & $\begin{array}{c}\text { Steady State Value } \\
\text { without Default }\end{array}$ & Variable & $\begin{array}{c}\text { Steady State Value } \\
\text { in the presence of Default }\end{array}$ \\
\hline$\hat{\beta}$ & 0.9900 & $\hat{\beta}$ & 0.9900 \\
$c^{\theta}$ & 0.4883 & $c^{\theta}$ & 0.4698 \\
$\hat{d}^{\theta}$ & 31.6417 & $\hat{d}^{\theta}$ & 9.8030 \\
$\hat{d}^{F}$ & 33.1567 & $\hat{d}^{F}$ & 10.9953 \\
$\hat{d}^{I B}$ & 31.8992 & $\hat{d}^{I B}$ & 9.9615 \\
$g_{G}$ & 1.0300 & $g_{G}$ & 1.0300 \\
$L^{\theta}$ & 0.4920 & $L^{\theta}$ & 0.4801 \\
$\hat{p}$ & 70.1185 & $\hat{p}$ & 24.5577 \\
$\hat{w}$ & 67.3955 & $\hat{w}$ & 22.1877 \\
$\hat{\pi}^{\psi}$ & 0.2601 & $\hat{\pi}^{\psi}$ & 0.2658 \\
$\hat{\pi}^{\delta}$ & 0.2601 & $\hat{\pi}^{\delta}$ & 0.2617 \\
$r^{d}=r^{F}=r^{I B}$ & 0.04040 & $r^{d}$ & 0.05091 \\
& & $r^{F}$ & 0.1068 \\
& & $r^{I B}$ & 0.0726 \\
& & $v^{d}$ & 0.9900 \\
& & $v^{F}$ & 0.9691 \\
& & $v^{I B}$ & 0.9800 \\
\hline
\end{tabular}




\section{Appendix 2}

\section{New Keynesian Model}

The log linearized equations of the model are:

\section{IS Curve}

$$
\tilde{y}_{t}=\gamma_{1} \tilde{y}_{t-1}+\gamma_{2} \tilde{y}_{t+1}+\gamma_{3}\left(m_{t}-p_{t}\right)+\epsilon_{t}^{I S}
$$

where

$$
\epsilon_{t}^{I S}=\rho^{I S} \epsilon_{t-1}^{I S}+e_{t}^{I S} ; \quad e_{t}^{I S \sim} N\left(0, \sigma_{I S}^{2}\right)
$$

and

$\tilde{y}_{t} \equiv$ output gap in period $t$

$m_{t} \equiv$ stock of money in period $t$

$p_{t} \equiv$ aggregate price level in period $t$

\section{Phillips Curve}

$$
p_{t}-p_{t-1}=E_{t}\left\{p_{t+1}\right\}-p_{t}+\beta_{1} \tilde{y}_{t}+\epsilon_{t}^{P C}
$$

where

$$
\epsilon_{t}^{P C}=\rho^{P C} \epsilon_{t-1}^{P C}+e_{t}^{P C} ; \quad e_{t}^{P C \sim} N\left(0, \sigma_{P C}^{2}\right)
$$

and

$$
E_{t}\left\{p_{t+1}\right\}=\alpha_{1} p_{t-1}+\left(1-\alpha_{1}\right) p_{t+1}
$$

Monetary Policy Shock

$$
m_{t}=m_{t-1}+\epsilon_{t}^{M P}
$$

where

$$
\epsilon_{t}^{M P}=\rho^{M P} \epsilon_{t-1}^{M P}+e_{t}^{P C} ; \quad e_{t}^{M P \sim} N\left(0, \sigma_{M P}^{2}\right)
$$

\section{Appendix 3}


Figure 2: Monetary Policy Shock in the New Keynesian Model
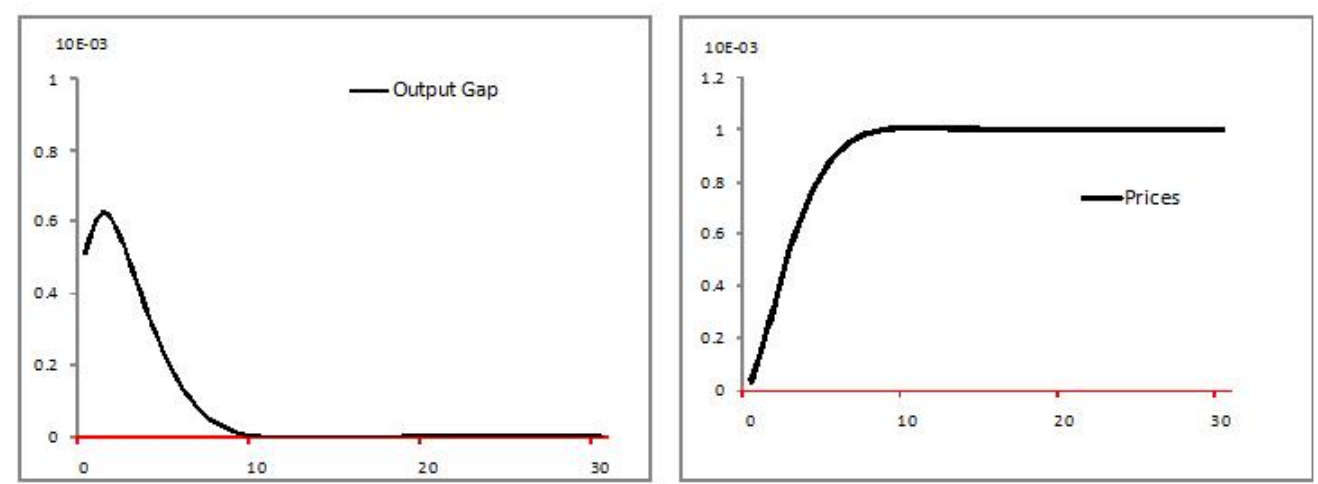

Figure 3: Monetary Policy Shock without Default
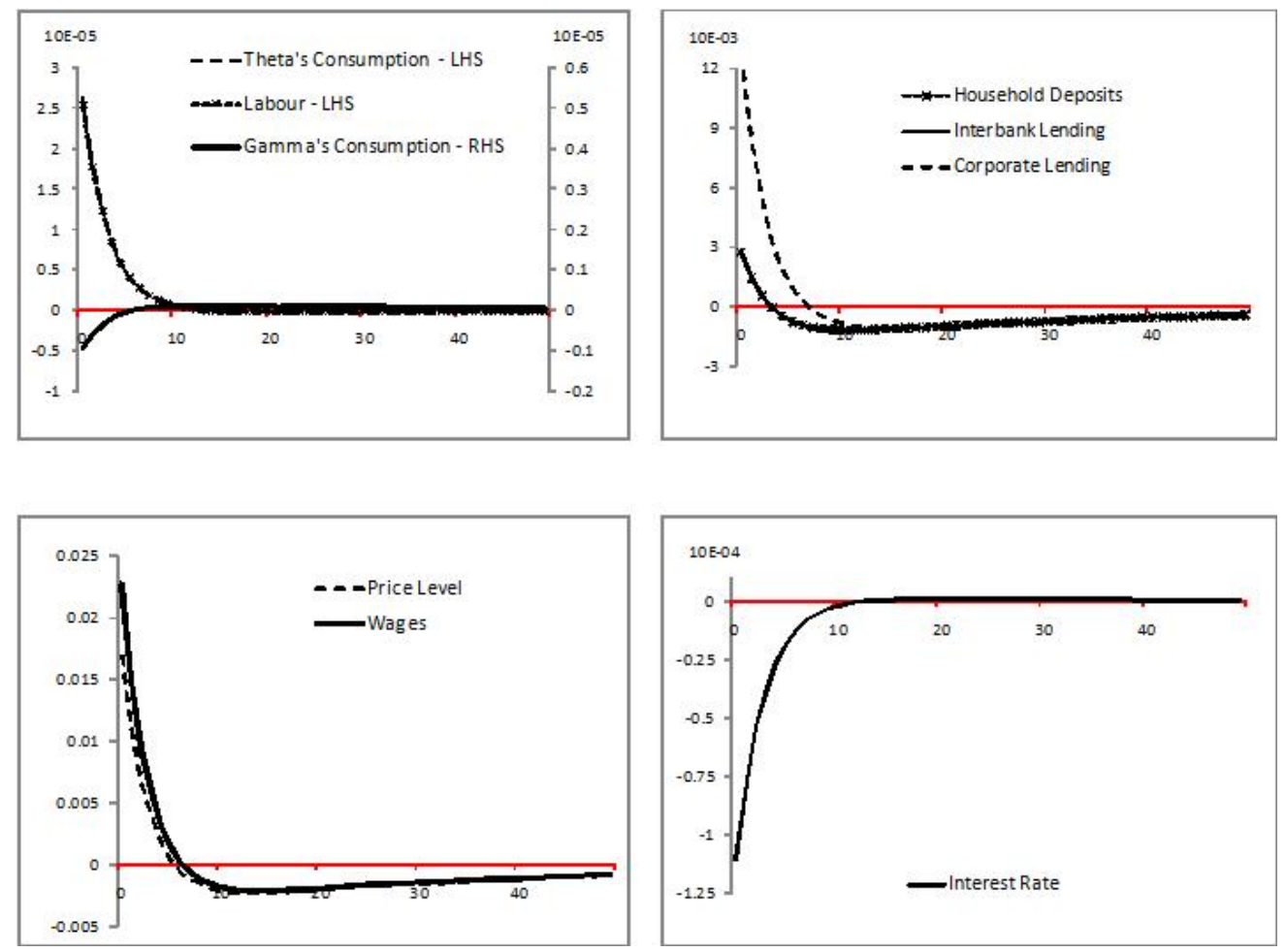
Figure 4: Monetary Policy Shock without Default (cont.)
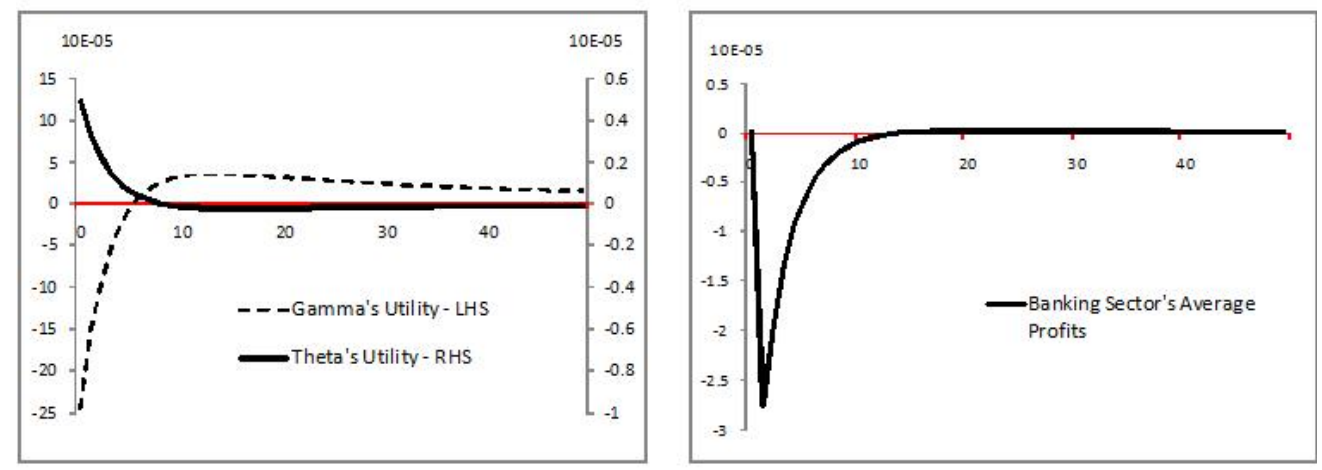

Figure 5: Monetary Policy Shock in the Presence of Default
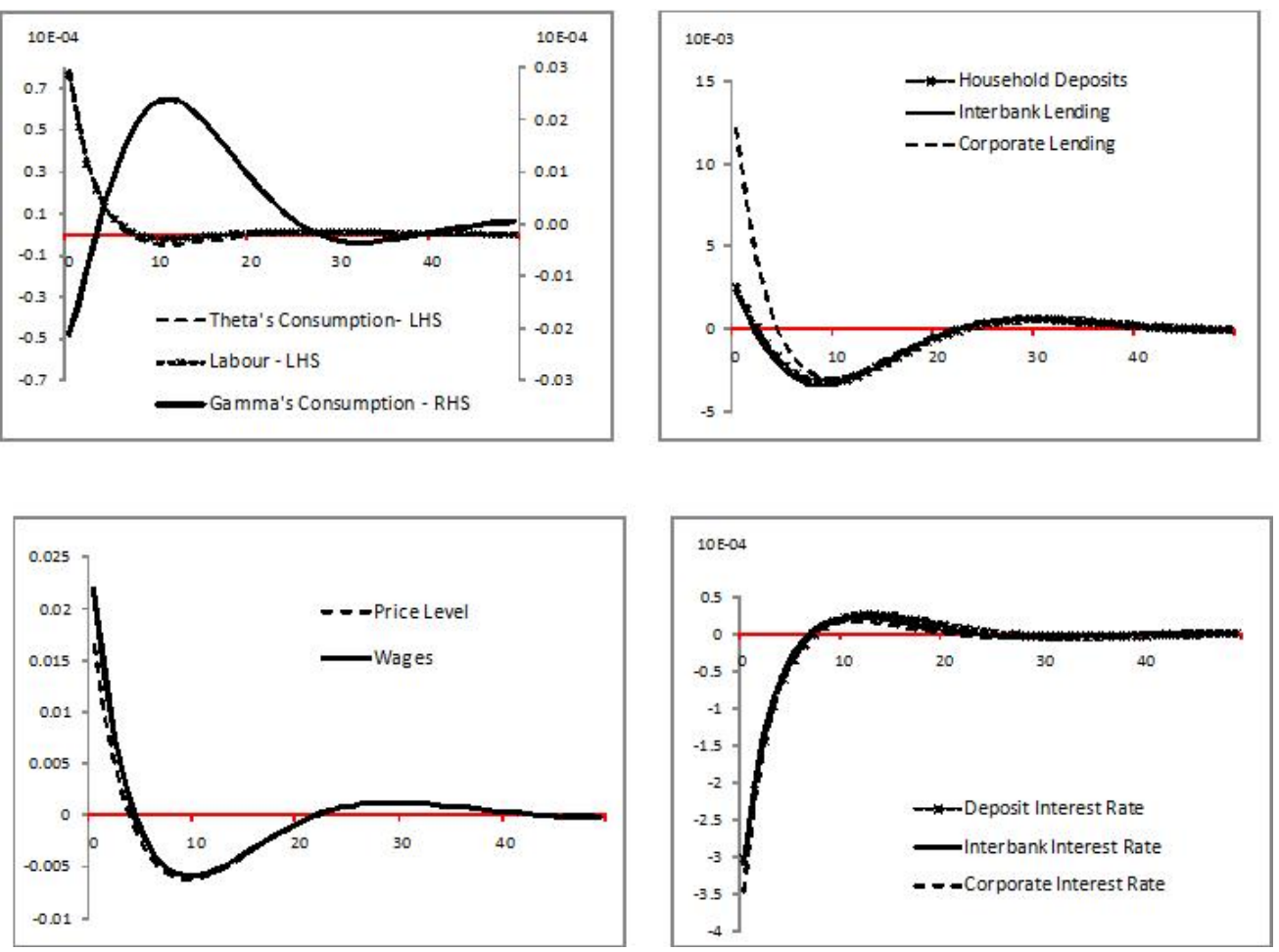
Figure 6: Monetary Policy Shock in the Presence of Default (cont.)
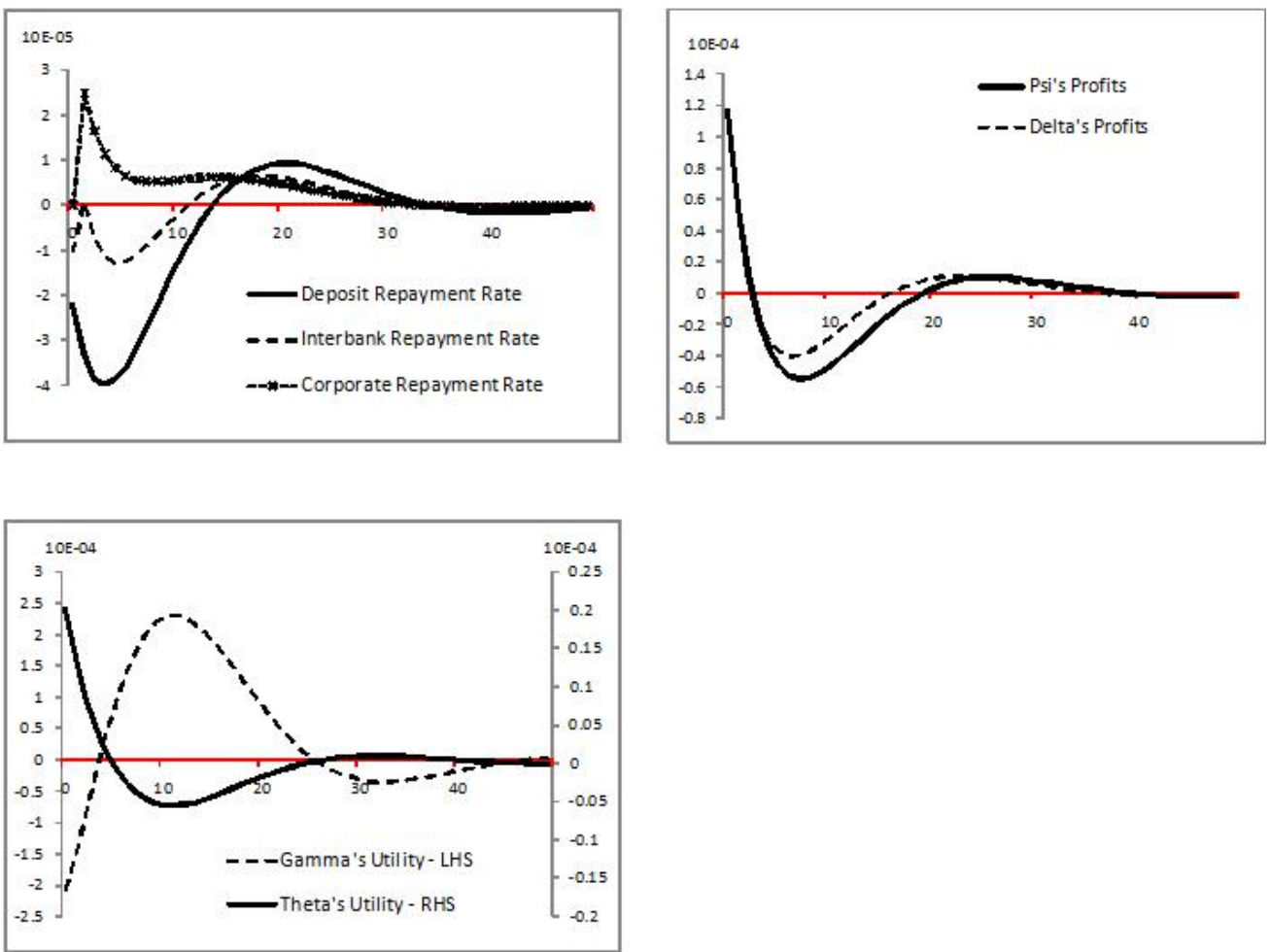

Figure 7: Fiscal Policy Shock in the New Keynesian Model
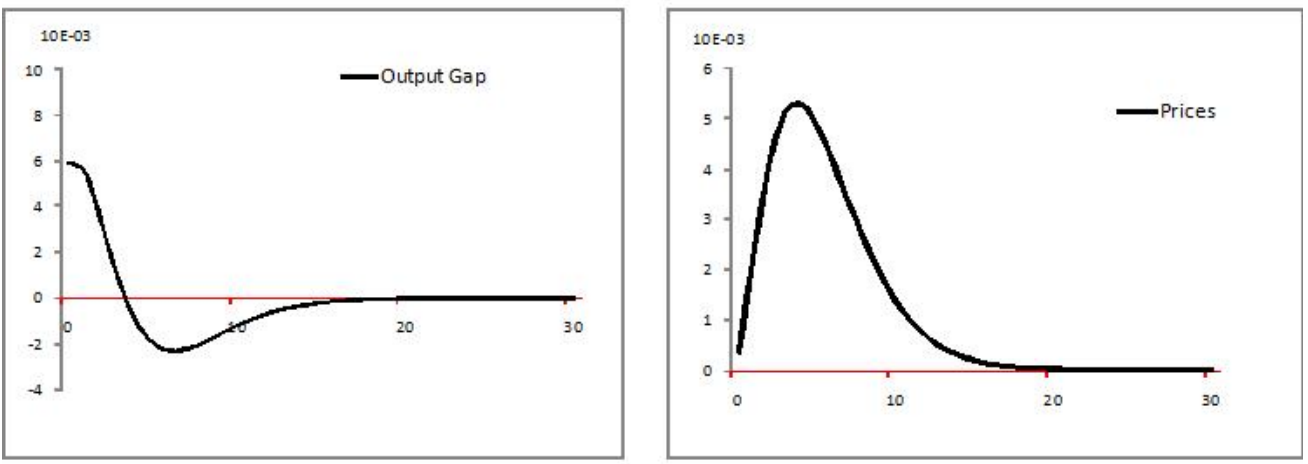
Figure 8: Fiscal Policy Shock without Default
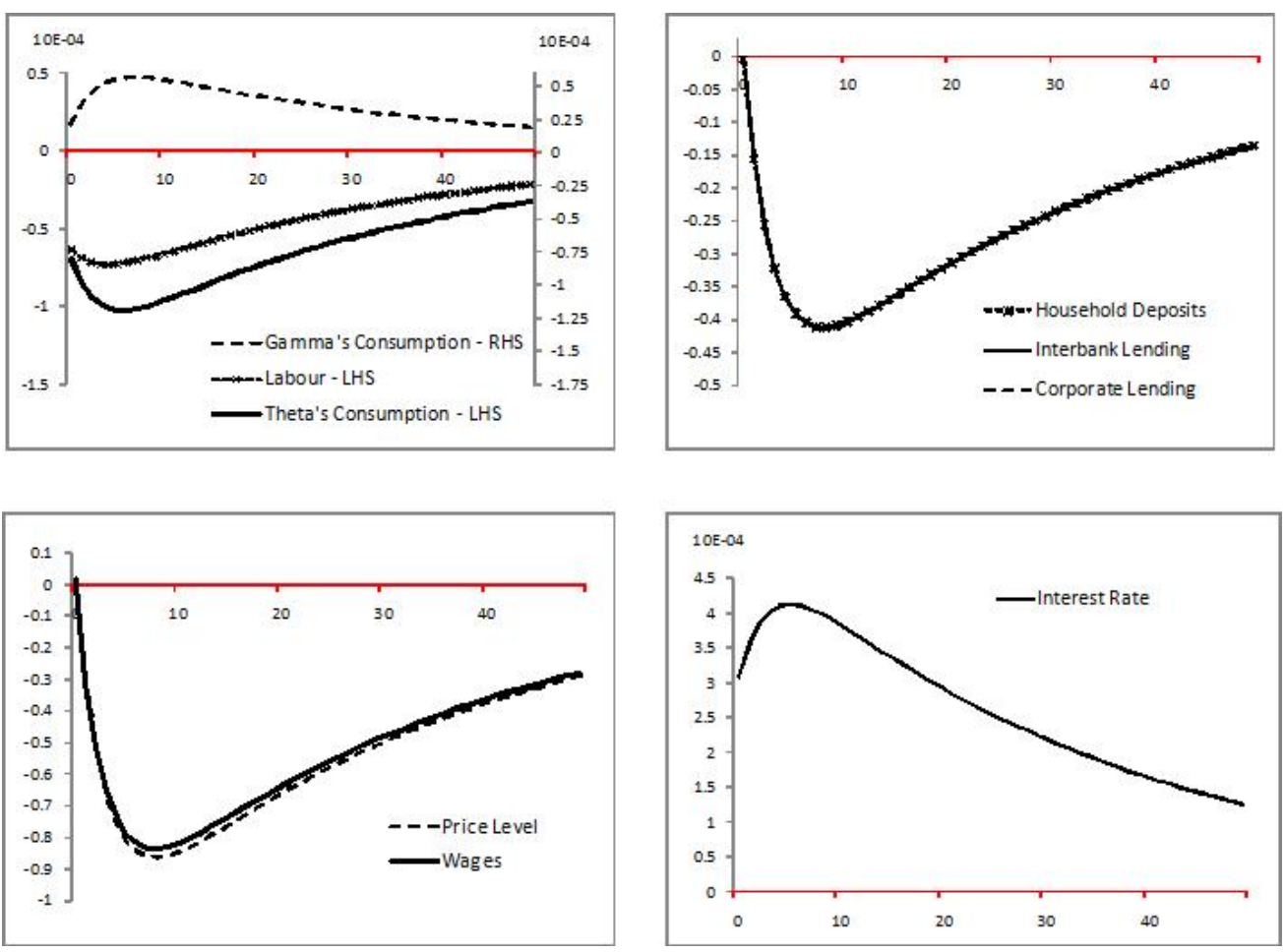

Figure 9: Fiscal Policy Shock without Default (cont.)
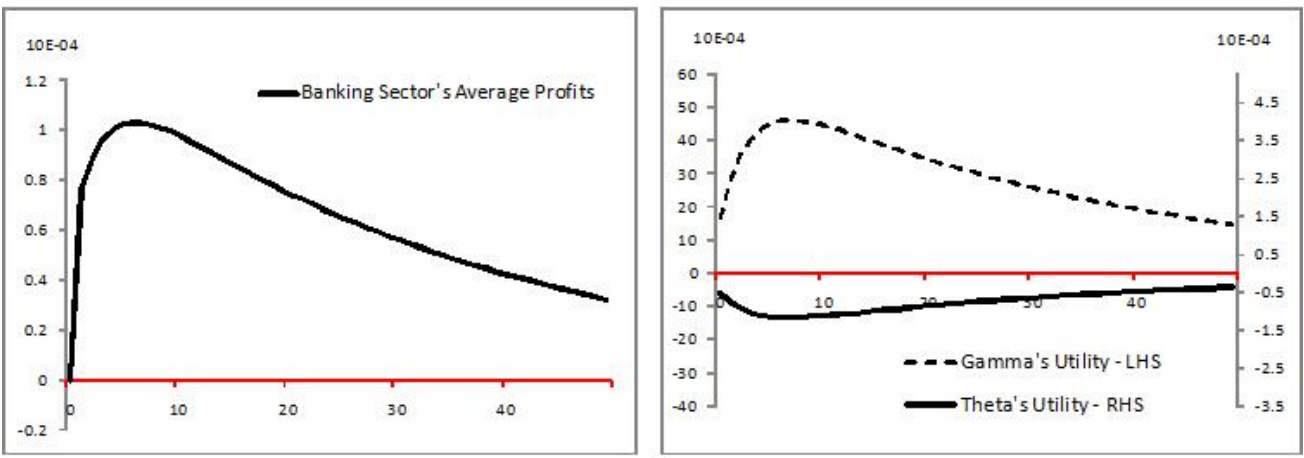
Figure 10: Fiscal Policy Shock in the Presence of Default
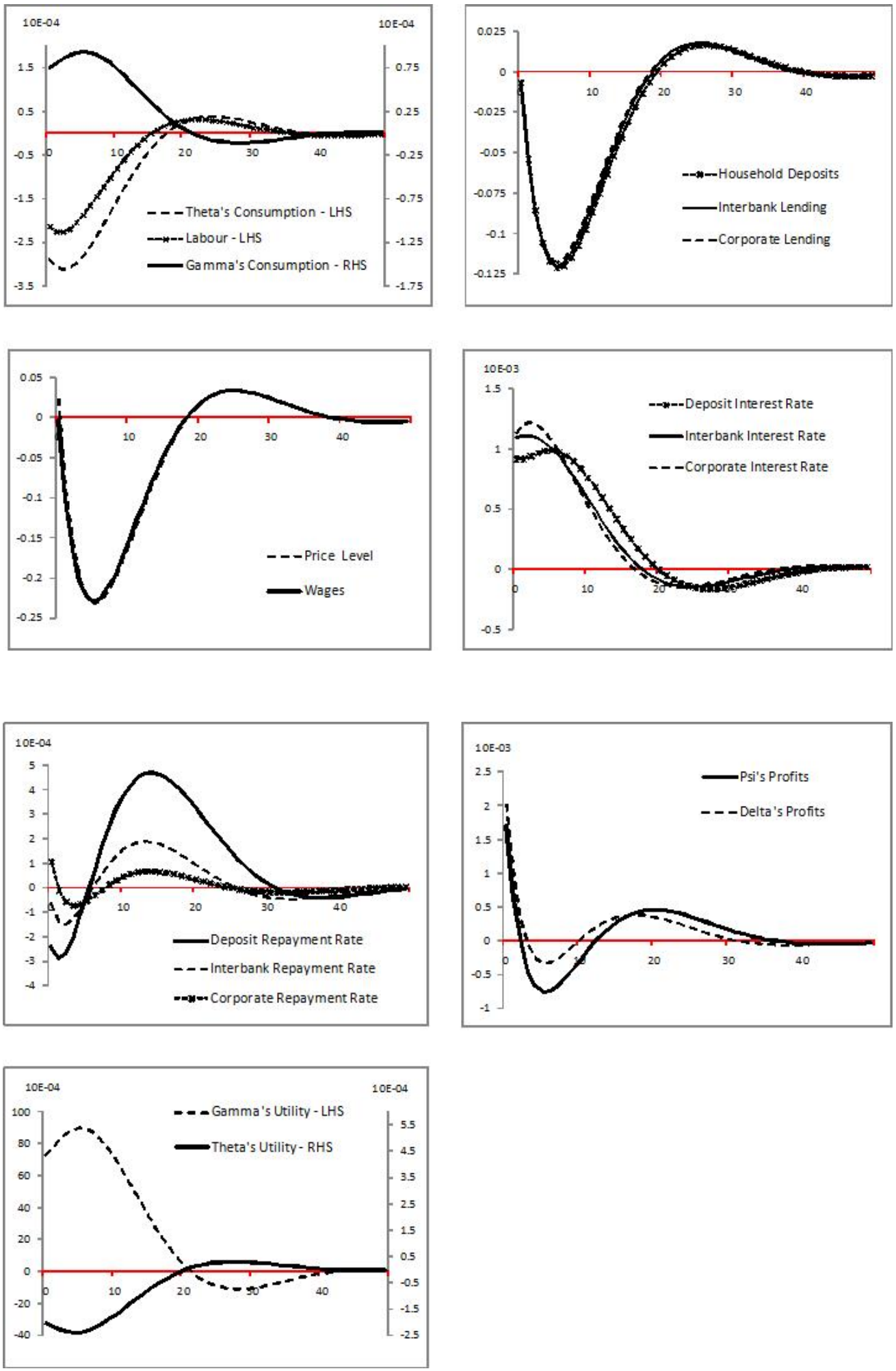
Figure 11: Technological Shock in the New Keynesian Model
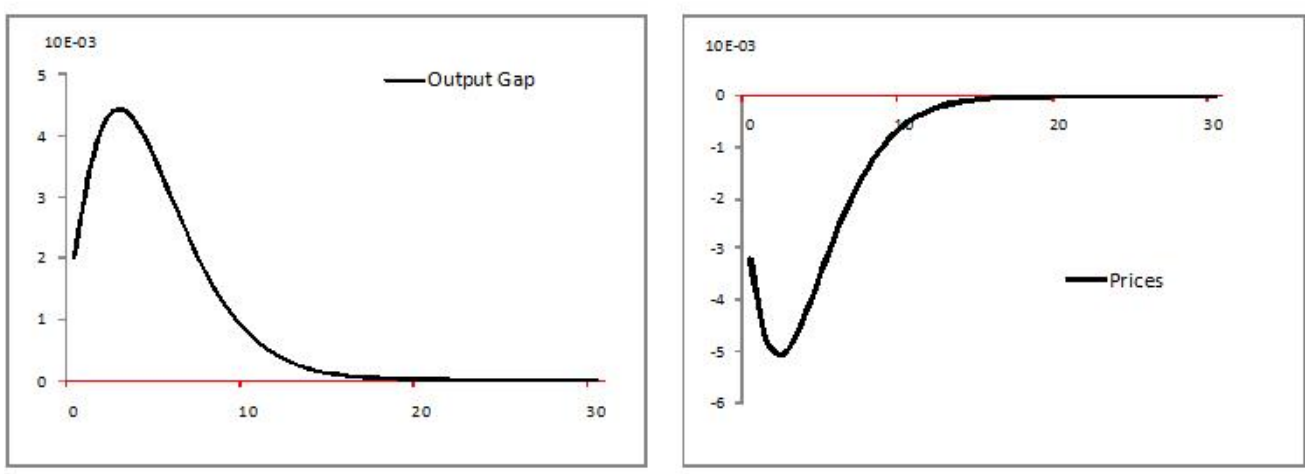

Figure 12: Technological Shock without Default
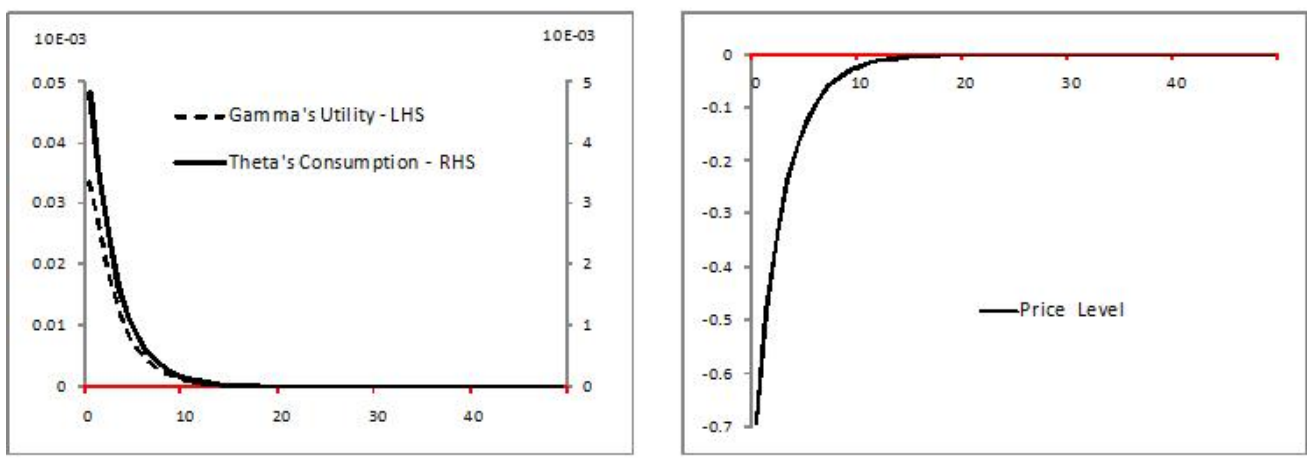
Figure 13: Technological Shock in the Presence of Default
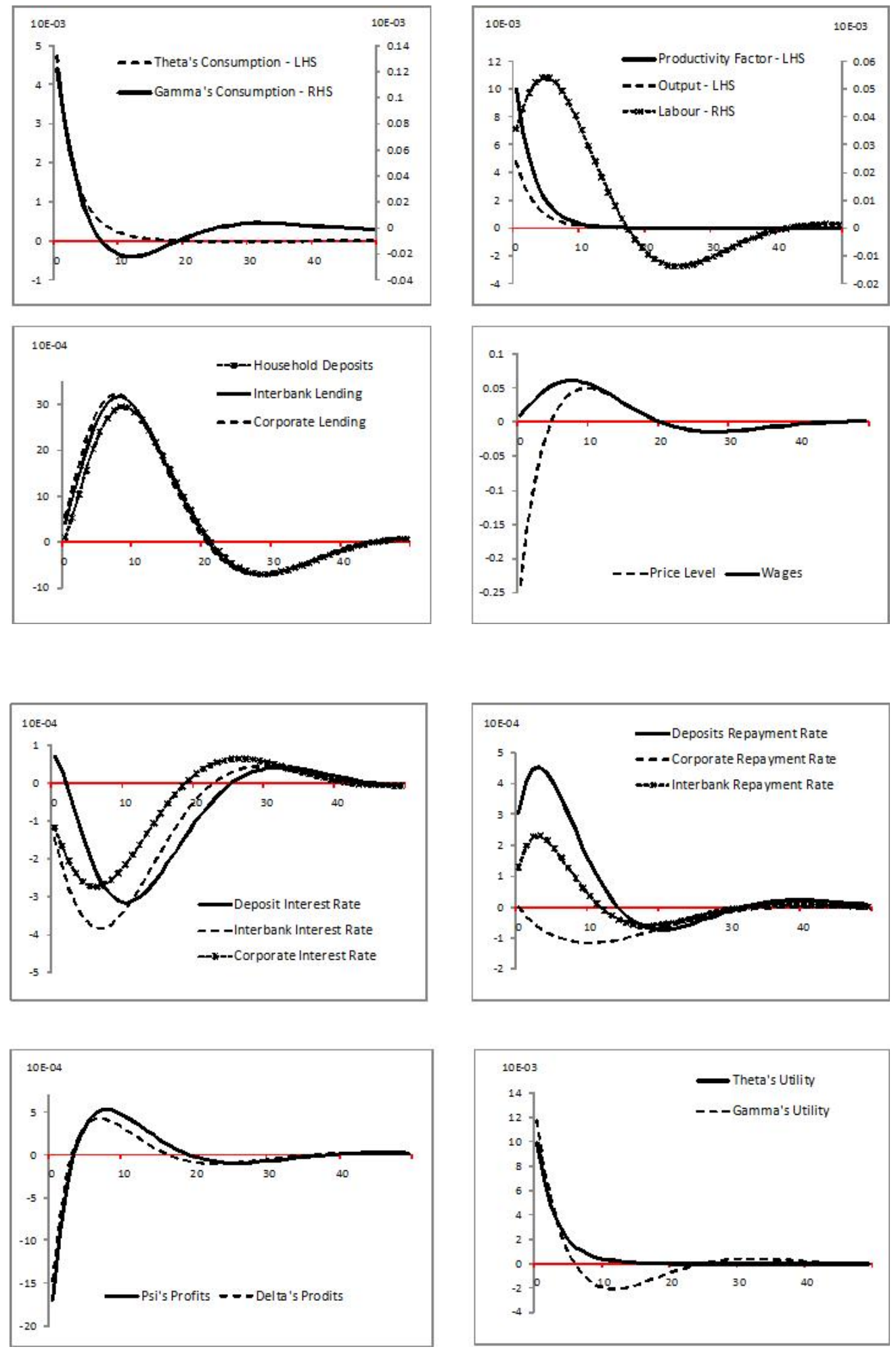
Figure 14: Tighter Regulatory Policy
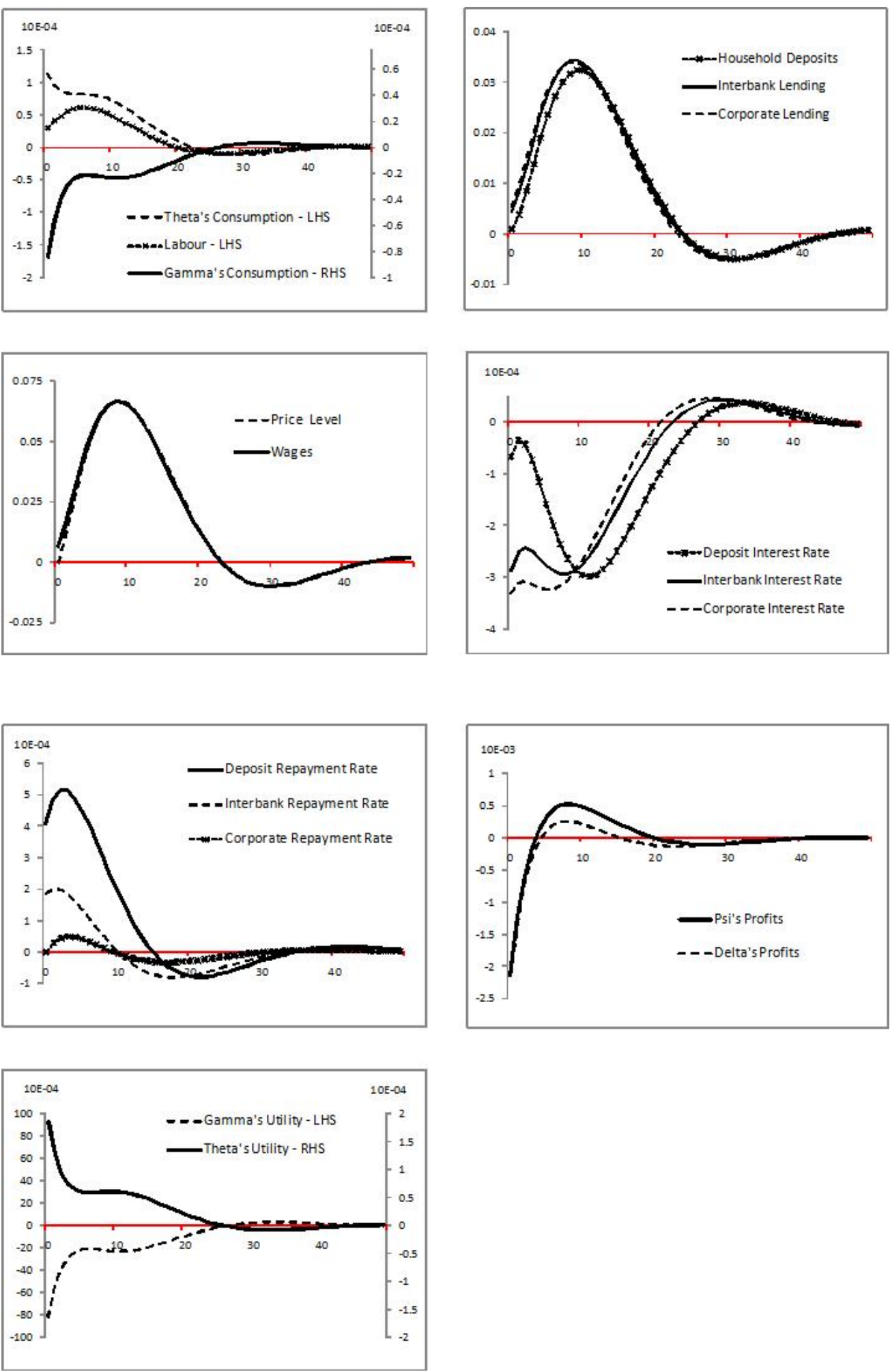


\section{CESifo Working Paper Series}

for full list see www.cesifo-group.org/wp

(address: Poschingerstr. 5, 81679 Munich, Germany, office@cesifo.de)

2825 Natasa Bilkic, Thomas Gries and Margarethe Pilichowski, Stay in School or Start Working? - The Human Capital Investment Decision under Uncertainty and Irreversibility, October 2009

2826 Hartmut Egger and Udo Kreickemeier, Worker-Specific Effects of Globalisation, October 2009

2827 Alexander Fink and Thomas Stratmann, Institutionalized Bailouts and Fiscal Policy: The Consequences of Soft Budget Constraints, October 2009

2828 Wolfgang Ochel and Anja Rohwer, Reduction of Employment Protection in Europe: A Comparative Fuzzy-Set Analysis, October 2009

2829 Rainald Borck and Martin Wimbersky, Political Economics of Higher Education Finance, October 2009

2830 Torfinn Harding and Frederick van der Ploeg, Is Norway's Bird-in-Hand Stabilization Fund Prudent Enough? Fiscal Reactions to Hydrocarbon Windfalls and Graying Populations, October 2009

2831 Klaus Wälde, Production Technologies in Stochastic Continuous Time Models, October 2009

2832 Biswa Bhattacharyay, Dennis Dlugosch, Benedikt Kolb, Kajal Lahiri, Irshat Mukhametov and Gernot Nerb, Early Warning System for Economic and Financial Risks in Kazakhstan, October 2009

2833 Jean-Claude Trichet, The ECB's Enhanced Credit Support, October 2009

2834 Hans Gersbach, Campaigns, Political Mobility, and Communication, October 2009

2835 Ansgar Belke, Gunther Schnabl and Holger Zemanek, Real Convergence, Capital Flows, and Competitiveness in Central and Eastern Europe, October 2009

2836 Bruno S. Frey, Simon Luechinger and Alois Stutzer, The Life Satisfaction Approach to Environmental Valuation, October 2009

2837 Christoph Böhringer and Knut Einar Rosendahl, Green Serves the Dirtiest: On the Interaction between Black and Green Quotas, October 2009

2838 Katarina Keller, Panu Poutvaara and Andreas Wagener, Does Military Draft Discourage Enrollment in Higher Education? Evidence from OECD Countries, October 2009

2839 Giovanni Cespa and Xavier Vives, Dynamic Trading and Asset Prices: Keynes vs. Hayek, October 2009 
2840 Jan Boone and Jan C. van Ours, Why is there a Spike in the Job Finding Rate at Benefit Exhaustion?, October 2009

2841 Andreas Knabe, Steffen Rätzel and Stephan L. Thomsen, Right-Wing Extremism and the Well-Being of Immigrants, October 2009

2842 Andrea Weber and Christine Zulehner, Competition and Gender Prejudice: Are Discriminatory Employers Doomed to Fail?, November 2009

2843 Hadi Salehi Esfahani, Kamiar Mohaddes and M. Hashem Pesaran, Oil Exports and the Iranian Economy, November 2009

2844 Ruediger Bachmann and Christian Bayer, Firm-Specific Productivity Risk over the Business Cycle: Facts and Aggregate Implications, November 2009

2845 Guglielmo Maria Caporale, Burcu Erdogan and Vladimir Kuzin, Testing for Convergence in Stock Markets: A Non-Linear Factor Approach, November 2009

2846 Michèle Belot and Jan Fidrmuc, Anthropometry of Love - Height and Gender Asymmetries in Interethnic Marriages, November 2009

2847 Volker Nitsch and Nikolaus Wolf, Tear Down this Wall: On the Persistence of Borders in Trade, November 2009

2848 Jan K. Brueckner and Stef Proost, Carve-Outs Under Airline Antitrust Immunity, November 2009

2849 Margarita Katsimi and Vassilis Sarantides, The Impact of Fiscal Policy on Profits, November 2009

2850 Scott Alan Carson, The Relationship between Stature and Insolation: Evidence from Soldiers and Prisoners, November 2009

2851 Horst Raff and Joachim Wagner, Intra-Industry Adjustment to Import Competition: Theory and Application to the German Clothing Industry, November 2009

2852 Erkki Koskela, Impacts of Labor Taxation with Perfectly and Imperfectly Competitive Labor Markets under Flexible Outsourcing, November 2009

2853 Cletus C. Coughlin and Dennis Novy, Is the International Border Effect Larger than the Domestic Border Effect? Evidence from U.S. Trade, November 2009

2854 Johannes Becker and Clemens Fuest, Source versus Residence Based Taxation with International Mergers and Acquisitions, November 2009

2855 Andreas Hoffmann and Gunther Schnabl, A Vicious Cycle of Manias, Crashes and Asymmetric Policy Responses - An Overinvestment View, November 2009

2856 Xavier Vives, Strategic Supply Function Competition with Private Information, November 2009 
2857 M. Hashem Pesaran and Paolo Zaffaroni, Optimality and Diversifiability of Mean Variance and Arbitrage Pricing Portfolios, November 2009

2858 Davide Sala, Philipp J.H. Schröder and Erdal Yalcin, Market Access through Bound Tariffs, November 2009

2859 Ben J. Heijdra and Pim Heijnen, Environmental Policy and the Macroeconomy under Shallow-Lake Dynamics, November 2009

2860 Enrico Spolaore, National Borders, Conflict and Peace, November 2009

2861 Nina Czernich, Oliver Falck, Tobias Kretschmer and Ludger Woessmann, Broadband Infrastructure and Economic Growth, December 2009

2862 Evžen Kočenda and Martin Vojtek, Default Predictors and Credit Scoring Models for Retail Banking, December 2009

2863 Christian Gollier and Martin L. Weitzman, How Should the Distant Future be Discounted when Discount Rates are Uncertain?, December 2009

2864 Tiberiu Dragu and Mattias Polborn, Terrorism Prevention and Electoral Accountability, December 2009

2865 Torfinn Harding and Beata Smarzynska Javorcik, A Touch of Sophistication: FDI and Unit Values of Exports, December 2009

2866 Matthias Dischinger and Nadine Riedel, There's no Place like Home: The Profitability Gap between Headquarters and their Foreign Subsidiaries, December 2009

2867 Andreas Haufler and Frank Stähler, Tax Competition in a Simple Model with Heterogeneous Firms: How Larger Markets Reduce Profit Taxes, December 2009

2868 Steinar Holden, Do Choices Affect Preferences? Some Doubts and New Evidence, December 2009

2869 Alberto Asquer, On the many Ways Europeanization Matters: The Implementation of the Water Reform in Italy (1994-2006), December 2009

2870 Choudhry Tanveer Shehzad and Jakob De Haan, Financial Reform and Banking Crises, December 2009

2871 Annette Alstadsæter and Hans Henrik Sievertsen, The Consumption Value of Higher Education, December 2009

2872 Chris van Klaveren, Bernard van Praag and Henriette Maassen van den Brink, Collective Labor Supply of Native Dutch and Immigrant Households in the Netherlands, December 2009

2873 Burkhard Heer and Alfred Maußner, Computation of Business-Cycle Models with the Generalized Schur Method, December 2009 
2874 Carlo Carraro, Enrica De Cian and Massimo Tavoni, Human Capital Formation and Global Warming Mitigation: Evidence from an Integrated Assessment Model, December 2009

2875 André Grimaud, Gilles Lafforgue and Bertrand Magné, Climate Change Mitigation Options and Directed Technical Change: A Decentralized Equilibrium Analysis, December 2009

2876 Angel de la Fuente, A Mixed Splicing Procedure for Economic Time Series, December 2009

2877 Martin Schlotter, Guido Schwerdt and Ludger Woessmann, Econometric Methods for Causal Evaluation of Education Policies and Practices: A Non-Technical Guide, December 2009

2878 Mathias Dolls, Clemens Fuest and Andreas Peichl, Automatic Stabilizers and Economic Crisis: US vs. Europe, December 2009

2879 Tom Karkinsky and Nadine Riedel, Corporate Taxation and the Choice of Patent Location within Multinational Firms, December 2009

2880 Kai A. Konrad, Florian Morath and Wieland Müller, Taxation and Market Power, December 2009

2881 Marko Koethenbuerger and Michael Stimmelmayr, Corporate Taxation and Corporate Governance, December 2009

2882 Gebhard Kirchgässner, The Lost Popularity Function: Are Unemployment and Inflation no longer Relevant for the Behaviour of Germany Voters?, December 2009

2883 Marianna Belloc and Ugo Pagano, Politics-Business Interaction Paths, December 2009

2884 Wolfgang Buchholz, Richard Cornes and Dirk Rübbelke, Existence and Warr Neutrality for Matching Equilibria in a Public Good Economy: An Aggregative Game Approach, December 2009

2885 Charles A.E. Goodhart, Carolina Osorio and Dimitrios P. Tsomocos, Analysis of Monetary Policy and Financial Stability: A New Paradigm, December 2009 